\title{
Verification of the new ECMWF ERA-Interim reanalysis over France
}

\author{
C. Szczypta $^{1}$, J.-C. Calvet ${ }^{1}$, C. Albergel ${ }^{1}$, G. Balsamo ${ }^{2}$, S. Boussetta ${ }^{2}$, D. Carrer ${ }^{1}$, S. Lafont ${ }^{1}$, and C. Meurey ${ }^{1}$ \\ ${ }^{1}$ CNRM/GAME, (Météo-France, CNRS), URA 1357, Toulouse, France \\ ${ }^{2}$ European Centre for Medium-range Weather Forecasts (ECMWF), Reading, UK
}

Received: 2 September 2010 - Published in Hydrol. Earth Syst. Sci. Discuss.: 22 September 2010

Revised: 20 February 2011 - Accepted: 21 February 2011 - Published: 25 February 2011

\begin{abstract}
An evaluation of the global ECMWF atmospheric reanalysis ERA-Interim (with a $0.5^{\circ}$ grid) is performed over France, based on the high resolution $(8 \mathrm{~km})$ SAFRAN atmospheric reanalysis. The ERA-Interim precipitation, Incoming Solar Radiation (ISR), air temperature, air humidity, and wind speed, are compared with their SAFRAN counterparts. Also, interpolated in situ ISR observations are used in order to consolidate the evaluation of this variable. The daily precipitation estimates produced by ERA-Interim over France correlate very well with SAFRAN. However, the values are underestimated by $27 \%$. A GPCP-corrected version of ERAInterim is less biased (13\%). The ERA-Interim estimates of ISR correlate very well with SAFRAN and with in situ observations on a daily basis. Whereas SAFRAN underestimates the ISR by $6 \mathrm{Wm}^{-2}$, ERA-Interim overestimates the ISR by $10 \mathrm{Wm}^{-2}$. In order to assess the impact of the ERA-Interim errors, simulations of the ISBA-A-gs land surface model are performed over the SMOSREX grassland site in southwestern France using ERA-Interim (with and without GPCP rescaling) and SAFRAN. Latent and sensible heat fluxes are simulated, together with carbon dioxide fluxes. The rescaled ERA-Interim performs better than the original ERA-Interim and permits to achieve flux scores similar to those obtained with SAFRAN.
\end{abstract}

\section{Introduction}

Soil moisture controls the exchange of water and heat energy between the land surface and the atmosphere through evaporation and plant transpiration. As a result, it is a key variable in short- and medium-range meteorological modelling,

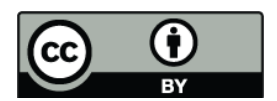

Correspondence to: J.-C. Calvet (jean-christophe.calvet@meteo.fr) climate and hydrological studies. A significant amount of studies have been conducted to obtain soil moisture products. For that purpose, land surface modelling (Dirmeyer et al., 1999; Georgakakos and Carpenter, 2006 among others) and remote sensing (Wagner et al., 1999a, b; Njoku et al., 2003; Kerr et al., 2007) techniques are used. Another variable, the Leaf Area Index (LAI), is defined as the total one sided area of photosynthetic tissues per unit ground surface area. Monitoring the distribution and changes of LAI is important to monitor vegetation. It is a fundamental variable in land-surface models. This variable controls the link between the biosphere and the atmosphere through various processes such as photosynthesis, respiration, transpiration, and rain interception. Long time series of accurate LAI products are essential for climate change studies, and to validate biochemical models (Brut et al., 2009).

In the framework of the HYMEX (HYdrological cycle in the Mediterranean EXperiment) project (HYMEX White Book, 2008) and particularly with the aim of developing a soil moisture and vegetation biomass climatology over $\mathrm{Eu}-$ rope and North Africa, this study investigates the quality of the European Center for Medium range Weather Forecasting (ECMWF) ERA-Interim (ERA-I) gridded atmospheric reanalysis over France, where a high resolution atmospheric analysis (Système d'Analyse Fournissant des Renseignements A la Neige - SAFRAN; Durand et al., 1993) is available. In the HYMEX project, this climatology will be used to drive land surface and runoff models, like the Total Runoff Integrating Pathways (TRIP; Oki et al., 1997) coupled to the Interactions between Soil Biosphere and Atmosphere (ISBA) model (Noilhan and Planton, 1989; Noilhan and Mahfouf, 1996) to build a soil moisture, LAI and river flow climatology over the Mediterranean basin. The TRIP model is able to isolate the river basins, inter-basin translation of water through river channels, as well as collect and route runoff to the river mouth(s) for all the major rivers (Oki et al., 1998).

Published by Copernicus Publications on behalf of the European Geosciences Union. 
The river flow simulated by TRIP can be used for the verification of the variables simulated by the land surface model because the river flow is driven by the runoff simulated by ISBA. Because the Mediterranean basin will probably be affected by climate change to a large extent (Gibelin and Déqué, 2003), it is important to build a monitoring system of the land surface variables and of the hydrological variables (e.g. river flow) over this region. The ISBA model is driven by atmospheric variables such as precipitation, downwelling radiation (shortwave and longwave), wind speed, air temperature and air humidity. Over France (Fig. 1), the SAFRAN analysis provides high resolution $(8 \mathrm{~km})$ gridded atmospheric variables. Over the whole Mediterranean domain, high resolution gridded atmospheric reanalyses are not available so far. The ERA-I data produced by the ECMWF could be used to drive the ISBA model at a spatial resolution of $0.5^{\circ}$, and to produce surface flux and runoff estimates.

In order to verify the quality of the low resolution ERAI data, the SAFRAN reanalysis can be used as a reference, over France. In the case of Incoming Solar Radiation (ISR), another high resolution product (Brion et al., 2005), based on in situ observations, is used as well. In this study, the ERAI estimates of atmospheric variables (precipitation, ISR, air temperature $\left(T_{\mathrm{a}}\right)$, air specific humidity $\left(q_{\mathrm{a}}\right)$ and wind speed) are compared for different temporal scales. First, a multiyear evaluation is performed over the 1991-2008 period, except for ISR as the reference data are only available over the 1995-2006 period. Second, ERA-I is compared in detail with the SAFRAN product for two years: 2001 and 2003. In 2003, France was affected by a large scale heat wave, which caused a severe drought in many areas. On the other hand, 2001 was a rather normal year, representative of the climatology. Finally, the impact of using ERA-I instead of SAFRAN in ISBA is assessed over a grassland site in southwestern France, for which surface flux and soil moisture profile observations are available.

\section{Data and methods}

This section presents ERA-I and the different data sets used for the verification of the ERA-I atmospheric variables at the surface. In order to assess the impact of using ERA-I instead of SAFRAN, the ISBA model was run using the two atmospheric reanalyses over the SMOSREX grassland site (De Rosnay et al., 2006) in southwestern France for a period of seven years (2001-2007), as in Albergel et al. (2010a, b). The simulated soil moisture and surface energy, water, and $\mathrm{CO}_{2}$ fluxes derived from ERA-I were compared with the reference SAFRAN-derived values at the SMOSREX site.

\subsection{Structure of data sets}

In this Section, the various atmospheric analyses used in this study are presented. Different time slices are considered depending on the availability of the data:

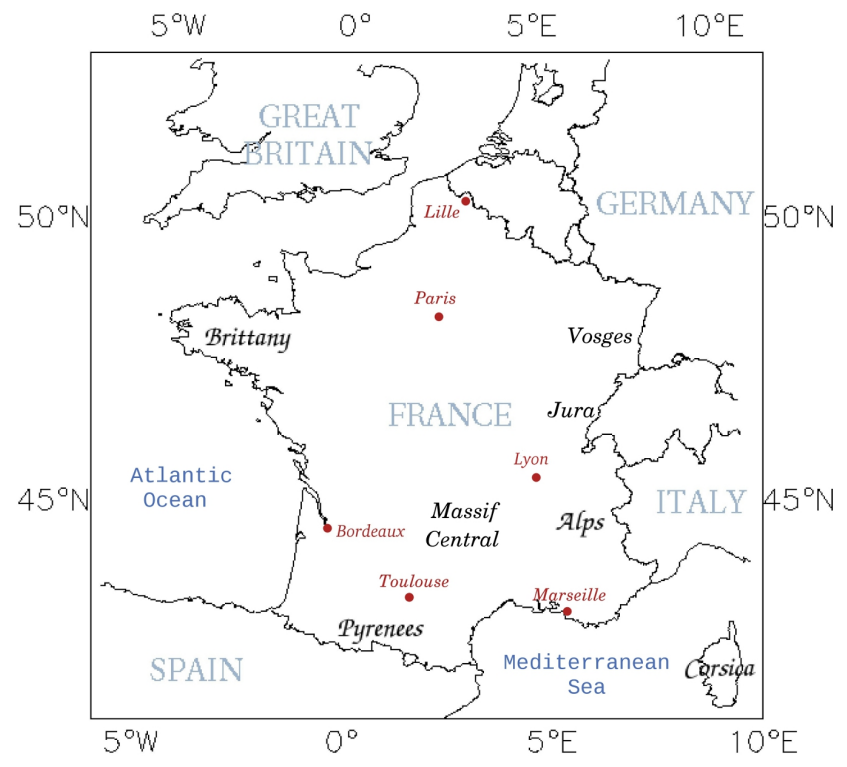

Fig. 1. Map of France, and main areas discussed in this study.

- 1991-2008: the SAFRAN and ERA-I analyses, and the GPCP precipitation products

- 1991-2007: the GPCC precipitation product

- 1995-2006: the Brion et al. (2005) ISR product

- 2001-2007: ISBA simulations for the SMOSREX site (Albergel et al., 2010b).

Since these products are available at different spatial resolutions, the comparisons performed in this study are based on the ERA-I $0.5^{\circ}$ resolution grid, corresponding to 308 grid cells over France. In particular, the high resolution $(8 \mathrm{~km})$ SAFRAN and Brion grid cells were aggregated at the $0.5^{\circ}$ resolution of ERA-I. Both SAFRAN and ERA-I analyses provide the atmospheric variables needed to drive land surface models: precipitation, ISR, $T_{\mathrm{a}}, q_{\mathrm{a}}$, wind speed, and the incoming longwave radiation. The latter is studied in Sect. 3.4.

\subsubsection{The SAFRAN analysis}

SAFRAN is a mesoscale atmospheric analysis system for surface variables. It produces an analysis at the hourly time step using atmospheric simulations and ground data observations. SAFRAN is based on climatically homogeneous zones and is able to take topography effects into account. Originally intended for mountainous areas, it was later extended to cover France. A detailed validation of the SAFRAN analysis over France (Quintana et al., 2008) and feedbacks from the operational implementation showed that SAFRAN was robust (wind, temperature, relative humidity, precipitation...) and provided accurate meteorological values to force ISBA. 
As far as precipitation is concerned, SAFRAN uses a large number of rain gauges and can be considered as a reference. The surface atmospheric variables are given at $2 \mathrm{~m}$ a.g.l., except for wind speed (10 m a.g.1.). In SAFRAN, the analyses of $T_{\mathrm{a}}, q_{\mathrm{a}}$ and wind speed are performed every six hours using all available observations. The analyzed values are linearly interpolated to a hourly time step. More information about these analyses can be found in Quintana-Segui et al. (2008).

\subsubsection{The ERA-I reanalysis}

The ERA-I reanalysis starts in January 1989 and provides meteorological data until present (the data are available in near real-time, with a delay of approximately one month). ERA-I relies on a 4-D-VAR system which uses observations within the windows of 15:00 UTC to 03:00 UTC and 03:00 UTC to 15:00 UTC (in the next day) to initialize forecast simulations starting at 00:00 UTC and 12:00 UTC, respectively. These atmospheric forcing data were projected on a grid of $0.5^{\circ} \times 0.5^{\circ}$ from the original Gaussian reduced grid (T255 reduced Gaussian grid of about $0.7^{\circ} \times 0.7^{\circ}$ ), at 3 $\mathrm{h}$ intervals (00:00, 03:00, 06:00, 09:00, 12:00, 15:00, 18:00 and 21:00 UTC). In order to allow sufficient spin-up, the first nine hours of the forecast simulations are not used. More information of the full ERA-I reanalysis products can be found in Simmons et al. (2007). Although ERA-I contains $2 \mathrm{~m}$ temperature and humidity variables diagnosed from the $10 \mathrm{~m}$ level, all the ERA-I surface atmospheric variables used in this study are given at $10 \mathrm{~m}$ a.g.l. (see Sect. 2.4).

\subsubsection{ERA-I rescaled precipitation}

A scale-selective rescaling procedure that corrects ERA-I 3-hourly precipitation was implemented by ECMWF in order to represent better the monthly accumulated precipitation provided by the Global Precipitation Climatology Project (GPCP v2.1) product. Hereinafter, the rescaled ERA-I precipitation will be referred to as ERA-I-R. The ERA-I-R precipitation is based on a rescaling factor computed by: (1) interpolating conservatively the GPCP $2.5^{\circ} \times 2.5^{\circ}$ grid to its equivalent T95 grid, (2) interpolating conservatively the ERA-I T255 Gaussian grid to the same T95 Gaussian grid, (3) computing the rescaling factor at this low resolution grid and by (4) interpolating conservatively the rescaling factor from the T95 to the T255 resolution (Balsamo et al., 2010). For this reason, this method preserves the small scale features of ERA-I while the rescaled monthly totals are consistent with the GPCP observations. It must be noted that the rescaling method was verified using available high resolution precipitation estimates over the USA. Furthers details of the specific method used to rescale ERA-I can be found in Balsamo et al. (2010).

\subsubsection{GPCC and GPCP monthly precipitation data sets}

In order to assess the performance of ERA-I and ERA-I-R precipitation products, two other precipitation products were evaluated over France: GPCC (product of the Global Precipitation Climatology Centre, Rudolf et al., 2005) and GPCP (product of the Global Precipitation Climatology Project, Adler et al., 2003).

The Global Precipitation Climatology Centre (GPCC) provides global monthly precipitation analyses for monitoring and research of the earth's climate at $1^{\circ} \times 1^{\circ}$ resolution. GPCC published in 2008 a new global monthly precipitation climatology for the 1901-2007 period. The GPCC database comprises monthly quality-controlled precipitation totals from more than 70000 rain gauge stations in the world (Fuchs et al., 2009).

The GPCP v2.1 data is a monthly climatology provided globally at $2.5^{\circ} \times 2.5^{\circ}$ resolution and covering the period from 1979 to present. The general objective of GPCP is to combine the precipitation information available from several sources into a merged product. The GPCP data set combines different sources of data, such as satellite data, together with rain gauge data which are assembled and analyzed by the GPCC and by the Climate Prediction Center of the National Oceanic and Atmospheric Administration (NOAA). GPCP v2.0 is described in Adler et al. (2003). The processing strategy for GPCP v2.1 is essentially similar as described for v2.0 but version 2.1 takes advantage of the improved GPCC gauge analysis and the usage of additional satellitederived products such as the Outgoing Longwave Radiation Precipitation Index (OPI) data from the NOAA series satellites. More information on these improvements is given in Huffman et al. (2009).

\subsubsection{Brion ISR product}

In SAFRAN, the ISR is not derived from ground observations, but calculated by a radiation scheme. From 1994 onward, another product based on ground observations is available (Brion et al., 2005). Brion et al. (2005) have shown that the interpolated ground observations are often closer to independent observations than SAFRAN. As ground observations are scarce in mountainous areas, the quality of the Brion product is poor in these regions. Therefore, above $500 \mathrm{~m}$ a.s.l., the Brion data are not used. Moreover, the Brion product is not available for Corsica. Finally, the Brion product covers $76 \%$ of the France domain (235 grid points).

\subsection{Precipitation}

Precipitation is the most important variable for a great number of applications, but, at the same time, this variable is not easily mapped because of its discontinuity in space and time. Along with SAFRAN and the ERA-I original data, a number of precipitation products are considered: ERA-I-R, GPCP and GPCC (see Sects. 2.1.3 and 2.1.4). 
In order to verify the quality of ERA-I and to assess to what extent the rescaling of ERA-I improves the precipitation estimates, a comparison of the precipitation data sets is performed at different temporal and spatial scales. First, average precipitation values for the whole France domain, derived from ERA-I and ERA-I-R, are compared with SAFRAN with monthly and daily time steps. Second, the same comparison is performed at the scale of the ERA-I grid $\left(0.5^{\circ}\right)$. Three scores are considered: the square correlation coefficient (temporal correlation), the mean bias, and the root mean square error (RMSE). Also, the spatial correlations between SAFRAN and either ERA-I or ERA-I-R are investigated, at different seasons. Finally, a month-by-month comparison between all the data sets presented before is made for the years 2001 and 2003.

\subsection{Incoming Solar Radiation (ISR)}

For the ISR variable, ERA-I and SAFRAN are both compared in detail with the Brion data set, for the years 2001 and 2003. A multiyear evaluation is performed over the 1995-2006 period. The ERA-I ISR is also compared with SAFRAN for the whole domain (308 grid cells). As for precipitation, the inter-comparison of ISR products is performed at different temporal and spatial scales.

\subsection{Air temperature, air humidity and wind speed}

Air temperature, air humidity and wind speed provided by ERA-I (Simmons et al., 2010) are compared with SAFRAN. The comparison is performed at two times: morning (06:00 UTC) and noon (12:00 UTC). For both morning and noon variables, statistical scores (square correlation coefficient, bias and RMSE) were computed for the whole 1991-2008 period. In the case of $T_{\mathrm{a}}$ and $q_{\mathrm{a}}$, two additional times were considered, in order to better sample the diurnal cycle: 00:00 UTC and 18:00 UTC. It is important to note that the data are estimated at different heights. In SAFRAN, $T_{\mathrm{a}}$ and $q_{\mathrm{a}}$ are analyzed at $2 \mathrm{~m}$ and wind speed at $10 \mathrm{~m}$ above the surface. In this study, the ERA-I instantaneous atmospheric variables are all extracted from the lowest atmospheric model level, at $10 \mathrm{~m}$ above the surface. Indeed, Pitman et al. (2009) showed that diagnosed $2 \mathrm{~m}$ temperature may vary a lot from one atmospheric analysis to another, and they suggested to use of the variables corresponding to the lowest atmospheric model level. This ensures the internal consistency of the fields and permits some flexibility in the choice of vertical interpolation within the surface boundary layer (e.g. using the stability functions of the modelling platform). However, in order to assess the impact of comparing SAFRAN and ERA-I $T_{\mathrm{a}}$ and $q_{\mathrm{a}}$ at different heights, the ERA-I $T_{\mathrm{a}}$ and $q_{\mathrm{a}}$ at $2 \mathrm{~m}$ were investigated for the year 2001 (see Sect. 3.3).

\subsection{Impact study on the SMOSREX site}

The impact of using ERA-I is assessed on the SMOSREX grassland site in southwestern France, based on existing SAFRAN-driven ISBA-A-gs simulations validated using ground observations (Albergel et al., 2010b).

\subsubsection{The SMOSREX experimental site}

The SMOSREX (Surface Monitoring Of the Soil Reservoir EXperiment) experimental site is located in Mauzac, near Toulouse, in the south of France (De Rosnay et al., 2006). It is a field campaign, which has been in operation since January 2001. Part of the SMOSREX experimental site is covered by a grassland of about $3.2 \times 10^{4} \mathrm{~m}^{2}(180 \mathrm{~m} \times 180 \mathrm{~m})$, mown once a year at wintertime. At SMOSREX, all the atmospheric forcing variables required to run ISBA-A-gs are measured: there are continuous ground measurements of atmospheric pressure, air humidity, air temperature, long-wave and short-wave incident radiation, rain rate, wind speed. A number of biophysical variables and surface fluxes are observed at the SMOSREX site: soil moisture (observed at ten depths and permitting to estimate the root-zone soil moisture content $w_{2}$ ), LAI, $\mathrm{CO}_{2}$, sensible heat $(H)$ and latent heat (LE) flux measurements.

\subsubsection{The ISBA-A-gs land surface model}

On the basis of ISBA (Noilhan and Planton, 1989; Noilhan and Mahfouf, 1996), Calvet et al. (1998) developed ISBAA-gs. It is a $\mathrm{CO}_{2}$ responsive version of ISBA which accounts for the effect of the atmospheric $\mathrm{CO}_{2}$ concentration and for the interactions between all environmental factors on the stomatal aperture. In ISBA-A-gs, photosynthesis and its coupling with stomatal conductance at a leaf level are accounted for. The vegetation net assimilation is computed and used as an input to a simple growth sub-model able to predict LAI. ISBA-A-gs is able to simulate GPP (Gross Primary Production), NEE (Net Ecosystem Exchange), LAI, the energy and mass fluxes such as sensible and latent heat fluxes, and soil moisture. ISBA-A-gs was implemented in the SURFEX (SURFace Externalisée) modelling platform (Le Moigne et al., 2009). In this study, SURFEX is used "offline", i.e. without coupling the land surface with an atmospheric model. First, a comparison of the different atmospheric variables between SAFRAN and ERA-I is performed on the grid cell corresponding to the SMOSREX site for a 18-year (1991-2008) period, corresponding to the available ERA-I dataset. Second, ISBA-A-gs is used to simulate the SMOSREX grassland for the 2001-2007 period, based on these two atmospheric forcing data sets. The same comparison is made with the ERA-I-R precipitation.

Over the SMOSREX grassland, a number of studies have shown that the ISBA-A-gs model is able to simulate, reasonably well, the water, energy, and $\mathrm{CO}_{2}$ fluxes, the LAI and 
Table 1. Precipitation over France in 2001, 2003 and over the 1991-2008 period: temporal and spatial squared correlation coefficient and RMSE of ERA-I and ERA-I-R with respect to the SAFRAN analysis.

\begin{tabular}{lcrrrrrr}
\hline $\begin{array}{l}\text { Comparison } \\
\text { type }\end{array}$ & Score & $\begin{array}{r}\text { ERA-I } \\
2001\end{array}$ & $\begin{array}{r}\text { ERA-I-R } \\
2001\end{array}$ & $\begin{array}{r}\text { ERA-I } \\
2003\end{array}$ & $\begin{array}{r}\text { ERA-I-R } \\
2003\end{array}$ & $\begin{array}{r}\text { ERA-I } \\
{[1991-2008]}\end{array}$ & $\begin{array}{r}\text { ERA-I-R } \\
\text { [1991-2008] }\end{array}$ \\
\hline $\begin{array}{l}\text { Temporal } \\
\text { (daily values) }\end{array}$ & $R^{2}$ & 0.89 & 0.89 & 0.90 & 0.90 & 0.89 & 0.89 \\
\hline RMSE $\left(\mathrm{mm} \mathrm{day}^{-1}\right)$ & 1.26 & 1.09 & 1.12 & 0.94 & 1.27 & 1.07 \\
\hline (308 grid cells) & $R^{2}$ & 0.59 & 0.58 & 0.48 & 0.54 & 0.48 & 0.54 \\
\hline
\end{tabular}
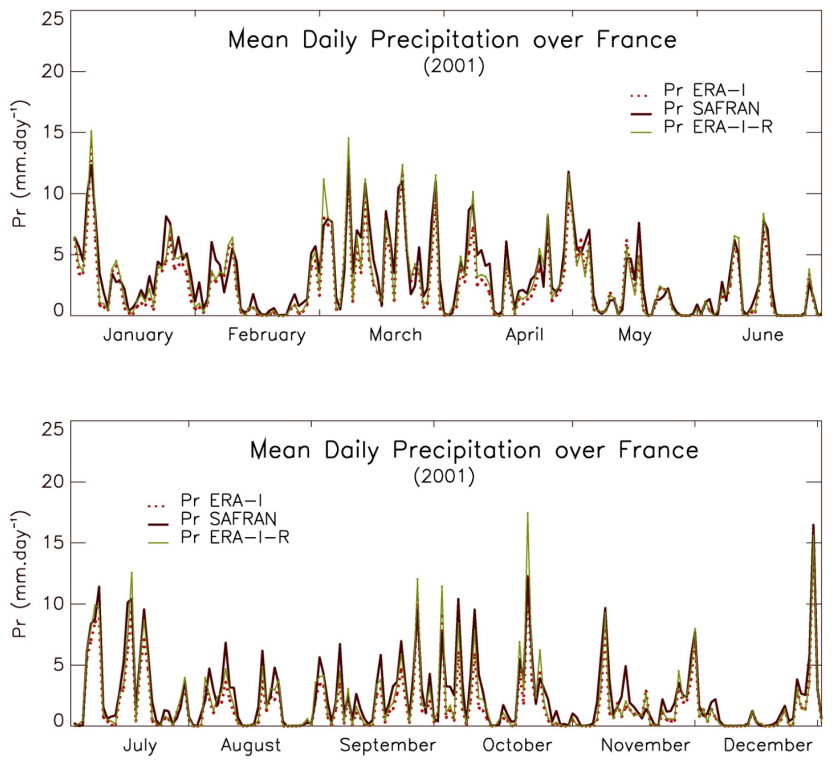

Fig. 2. Mean daily precipitation over France for SAFRAN, ERA-I and ERA-I-R: from (top) January to June 2001, and from (bottom) July to December 2001.

the root-zone soil moisture (e.g. Albergel et al., 2010a, b), using either the locally observed atmospheric forcing or the atmospheric forcing from the nearest SAFRAN grid point. In this study, ISBA-A-gs simulations are produced using the SAFRAN atmospheric forcing as a reference, and, also, using ERA-I and ERA-I-R. The simulated biophysical variables $\left(w_{2}\right.$, LAI and $\left.w_{\mathrm{g}}\right)$ and fluxes $\left(\mathrm{CO}_{2}, \mathrm{H}\right.$ and LE) are all considered for the 2001-2007 period (Albergel et al., 2010b). In order to evaluate the impact of using ERA-I or ERA-I-R in ISBA-A-gs, and to quantify the departure from the reference SAFRAN-driven simulation, a number of scores were computed, compared and analyzed: square correlation coefficient, mean bias, RMSE and, for soil moisture and LAI, the Nash-Sutcliffe coefficient (NASH).

In order to assess the relative impact on the ISBA-A-gs simulations of precipitation and ISR, which are the most biased ERA-I variables for this site, ISBA-A-gs was run in three configurations: (1) SAFRAN, (2) SAFRAN, except for SAFRAN precipitation replaced by the ERA-I-R precipitation, and (3) SAFRAN, except for SAFRAN ISR replaced by the ERA-I ISR.

\section{Results}

This section presents the results obtained for each atmospheric variable. The comparison is performed over the 1991-2008 period for all the forcing variables, except for ISR covering the 1995-2006 period. In addition, Tables 1, 3, and 4 give specific score values for the years 2001 and 2003.

\subsection{Precipitation data}

The purpose of this Section is to evaluate the ERA-I precipitation data against the precipitation derived from the SAFRAN analysis. In order to make a first assessment of ERA-I, Fig. 2 presents the mean daily precipitation over France for 2001, through time series derived from SAFRAN and ERA-I. At the scale of the whole country, the ERAI mean daily precipitation is very close to SAFRAN. Figure 2 shows that a significant correlation exists between the two data sets $\left(R^{2}=0.89\right)$ : the two curves are very similar throughout 2001 and the precipitation events occur at the same time. It can be noticed that differences between the two data sets may arise, particularly in January, February, April, August and September for this particular year. This bias is always in the same direction: on a daily scale, ERA-I tends to underestimate the precipitation.

Moreover, it appears that the ERA-I-R data set is closer to SAFRAN than the original ERA-I. The rescaling improves the quality of the precipitation estimates. Although smaller differences are observed between ERA-I-R and SAFRAN, it can be noted that when the precipitation is more abundant (in March, April, October 2001), ERA-I-R tends to overestimate the precipitation. Similar results are found for 2003 (not shown).

Figure 3 presents the same results as Fig. 2, except for monthly precipitation, over the whole 1991-2008 period, and is completed by Fig. 4, focusing on 2001 and 2003 with 
Table 2. Monthly precipitation over France for the 1991-2008 period as estimated by ERA-I and ERA-I-R vs. SAFRAN: performance of the spatial repartition of precipitation $\left(R^{2}\right.$, mean bias (ERA-I/ERA-I-R minus SAFRAN) and RMSE, for 308 grid-cells).

\begin{tabular}{|c|c|c|c|c|c|c|c|c|c|c|c|c|c|}
\hline & Month & Jan & Feb & Mar & Apr & May & Jun & Jul & Aug & Sep & Oct & Nov & Dec \\
\hline \multicolumn{2}{|c|}{$\begin{array}{l}\text { SAFRAN Mean Precipitation } \\
\qquad\left(\mathrm{mm} \mathrm{month}{ }^{-1}\right)\end{array}$} & 83 & 65 & 67 & 78 & 80 & 66 & 64 & 69 & 86 & 99 & 100 & 94 \\
\hline \multirow{3}{*}{ ERA-I } & $R^{2}$ & 0.23 & 0.38 & 0.49 & 0.56 & 0.69 & 0.75 & 0.75 & 0.61 & 0.53 & 0.48 & 0.39 & 0.26 \\
\hline & Bias (mm month $\left.{ }^{-1}\right)$ & -23 & -19 & -19 & -18 & -17 & -16 & -18 & -18 & -21 & -30 & -31 & -26 \\
\hline & $\operatorname{RMSE}\left(\mathrm{mm}\right.$ month $\left.^{-1}\right)$ & 30 & 24 & 24 & 24 & 21 & 20 & 21 & 23 & 28 & 36 & 38 & 34 \\
\hline \multirow{3}{*}{ ERA-I-R } & $R^{2}$ & 0.40 & 0.51 & 0.57 & 0.64 & 0.60 & 0.57 & 0.53 & 0.50 & 0.63 & 0.57 & 0.51 & 0.45 \\
\hline & Bias (mm month $\left.{ }^{-1}\right)$ & -11 & -9 & -13 & -10 & -8 & -7 & -8 & -8 & -9 & -15 & -15 & -12 \\
\hline & $\operatorname{RMSE}\left(\mathrm{mm}\right.$ month $^{-1}$ ) & 20 & 17 & 19 & 17 & 17 & 16 & 18 & 18 & 18 & 23 & 25 & 23 \\
\hline
\end{tabular}
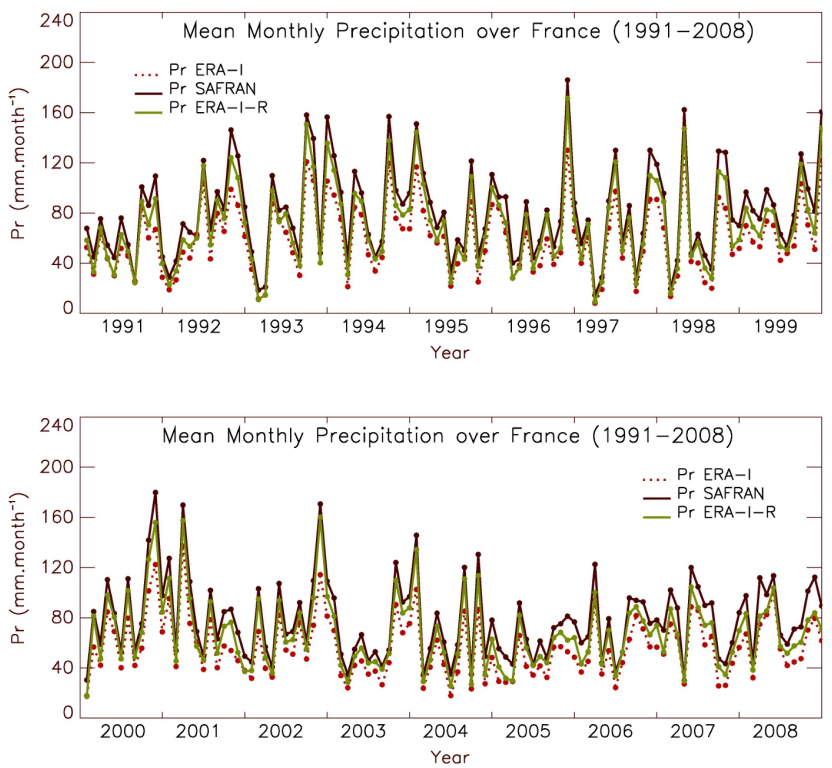

Fig. 3. Mean monthly precipitation over France for SAFRAN, ERA-I and ERA-I-R over the period 1991-2008: from (top) 1991 to 1999 , and from (bottom) 2000 to 2008 .

all the considered precipitation products (SAFRAN, ERA-I, ERA-I-R, GPCC and GPCP). Table 1 summarizes the ERA-I and ERA-I-R scores for 2001, 2003, and for the whole 19912008 period. Although the quality of the ERA-I precipitation may vary from one year to another (Dee et al., 2011) depending on the availability of the assimilated observations (e.g. satellite DMSP SSM/I brightness temperatures), the yearly scores (not shown) obtained in this study do not present any trend and do not vary much from one year to another. Indeed, while satellite data are critical over the ocean, they have less impact over land, where in situ observations are assimilated.

The square correlation coefficient between the daily precipitation estimates was computed for each ERA-I grid-cell (308 $R^{2}$ values) for the whole 1991-2008 period (6575 days) and these coefficients were plotted in Fig. 5 (left). Figure 5 presents the annual mean bias between ERA-I and SAFRAN, as well. The correlations obtained at the different grid points are good over a large part of France $\left(R^{2}>0.6\right)$. Topography is an issue as ERA-I does not perform very well, e.g., in the Alps and in the Pyrenees (Fig. 1), particularly in the eastern Pyrenees, which present complex terrains. For most grid cells, ERA-I underestimates precipitation. Also, this underestimation is larger in mountainous areas (Pyrenees, Alps). The same comparison is shown in Fig. 5 for ERA-I-R. Regarding the $R^{2}$ score, ERA-I-R performs better than the original ERA-I for a large part of France (in the center and in the north of France, in Corsica and close to the Atlantic ocean). However, the rescaling does not improve (and even degrades) the correlation in the eastern Pyrenees. Figure 5 illustrates the bias reduction induced by the rescaling: the number of grid cells with a low bias (less than $10 \mathrm{~mm} \mathrm{y}^{-1}$ ) increases and a number of points now present an overestimation of the precipitation, especially in southern France, close to the Mediterranean coast.

Figure 6 illustrates the spatial correlation of ERA-I and ERA-I-R with SAFRAN monthly precipitation maps, for four months (January, April, July, October) of 2001. Similar results (not shown) are obtained for 2003 and over the 1991-2008 period. Figure 6 shows, again, that ERA-I tends to underestimate precipitation. In July and in October 2001, it can be noted that a few outlier grid cells present a particularly large underestimation. These grid cells are located in the same region, depending on the weather situation, and correspond to intensive precipitation events related to fine scale processes occurring in mountainous areas. These processes are not represented well by ERA-I. Table 2 details the spatial performance of ERA-I and ERA-I-R on a monthly basis, for the 1991-2008 period. Table 2 shows that for ERA-I, the square correlation coefficients vary from 0.23 (in January) to 0.75 (in June and July). With ERA-I-R, $R^{2}$ varies from 0.40 (in January) to 0.64 (in April). Also, the bias and RMSE vary from one month to another. The 18-year evaluation of ERA-I 

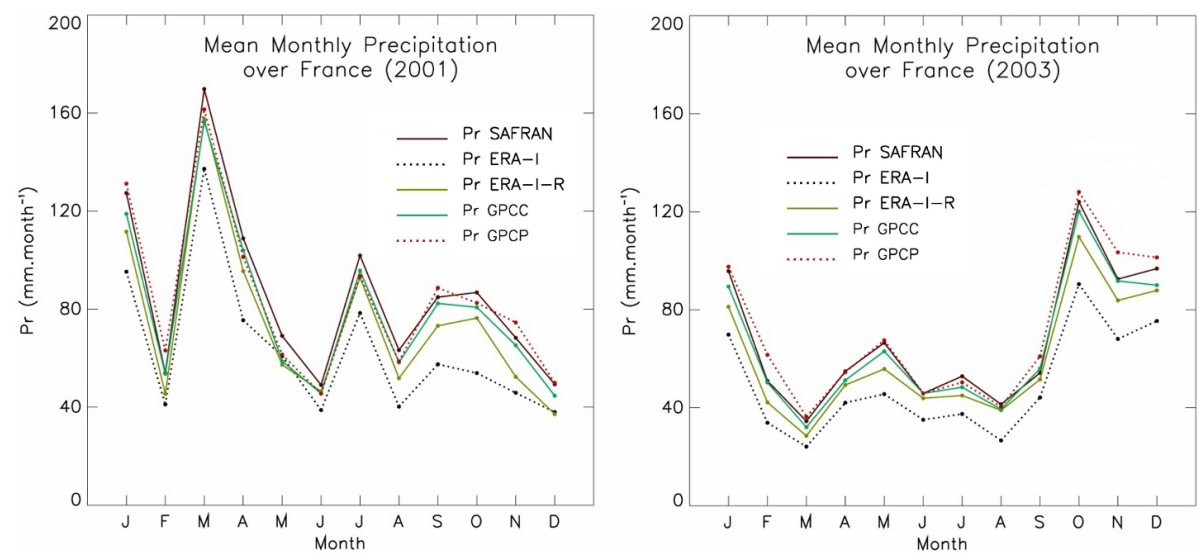

Fig. 4. Mean monthly precipitation over France for SAFRAN, ERA-I, ERA-I-R, GPCC and GPCP: (left) 2001, and (right) 2003.

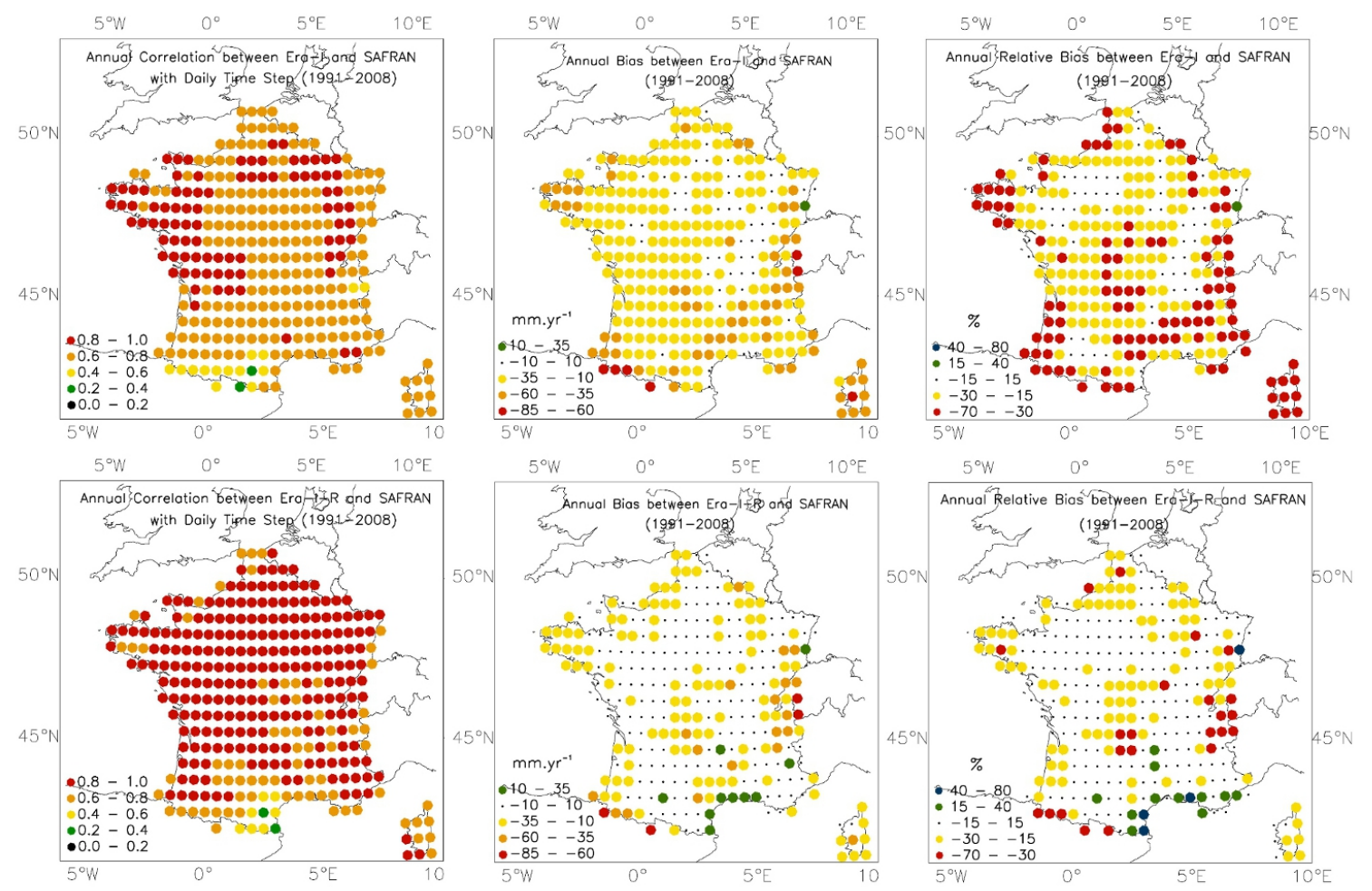

Fig. 5. Daily precipitation estimates over the 1991-2008 period: (top) ERA-I and (bottom) ERA-I-R vs. SAFRAN in terms of (left) temporal correlation $\left(R^{2}\right)$, (centre) mean bias and (right) mean relative bias (mean bias/mean precipitation value).

and ERA-I-R shows that the biases on precipitation depend significantly on the precipitation amount. At summertime, when the monthly precipitation presents low values, the biases are smaller. On average, ERA-I and ERA-I-R underestimate the reference SAFRAN data by $27 \%$ and by $13 \%$, respectively.

In order to assess the quality of ERA-I and ERA-I-R, relative to other global precipitation estimates, a comparison with the GPCC and GPCP data sets was performed. Figure 4 shows the mean monthly precipitation for 2001 and 2003, for all these data sets (SAFRAN, ERA-I, ERA-I-R, GPCP and GPCC). Both GPCC and GPCP monthly estimates are closer to SAFRAN than ERA-I (either rescaled or not). Table 3 presents the scores obtained for this comparison $(2001,2003$, and the whole 1991-2008 period) and shows that the correlation between GPCC, GPCP and SAFRAN (on a monthly basis) is very good and that the bias is small. ERA-I is rescaled with GPCP data but it can be noticed that the mean annual bias (for 2001 and 2003) between GPCP and SAFRAN is still smaller than the mean bias between ERA-I-R and 

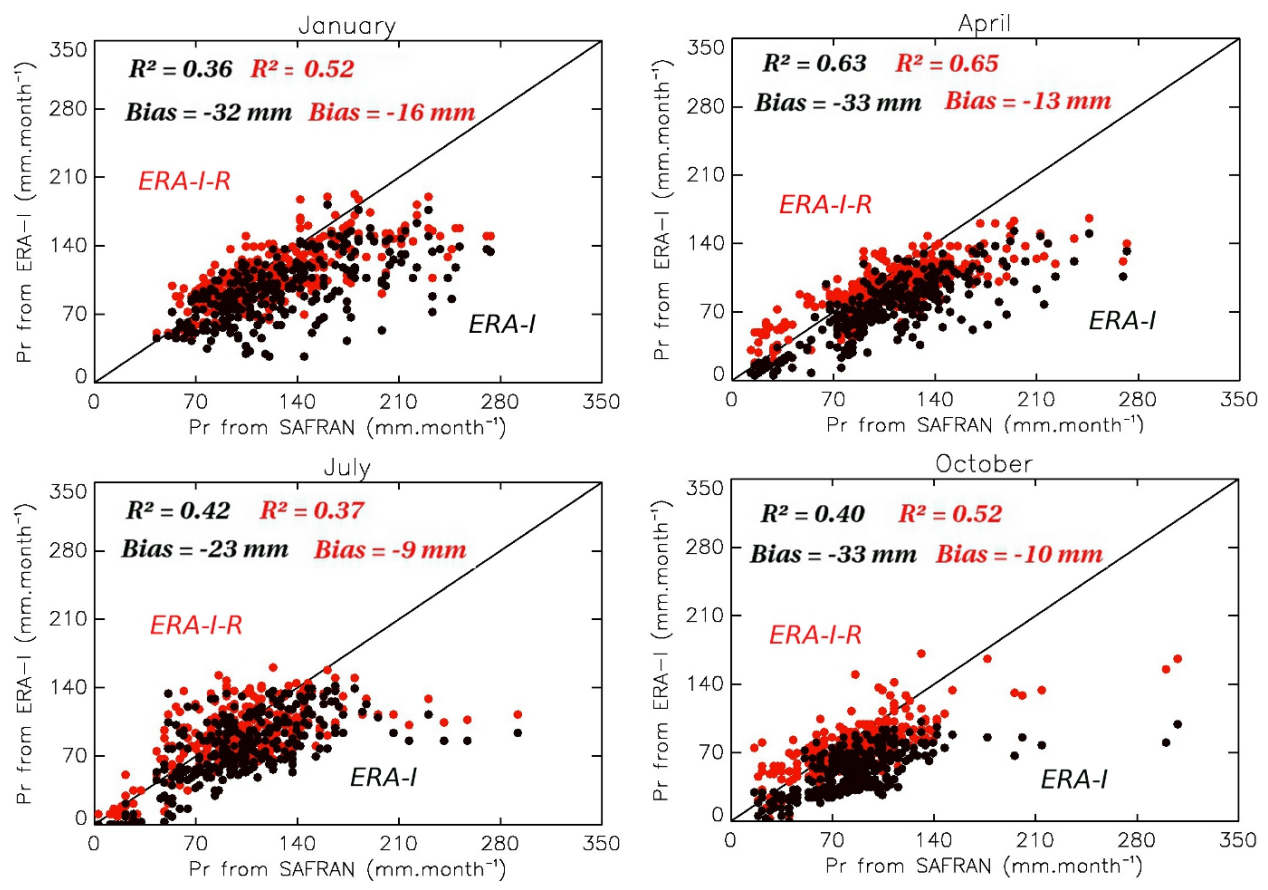

Fig. 6. Spatial correlation of the monthly precipitation data from ERA-I and ERA-I-R (308 grid-cells) with SAFRAN, in January, April, July, and October 2001.

Table 3. Representation of the seasonal variability in large scale precipitation products over France: mean monthly bias (large scale product minus SAFRAN), RMSE and squared correlation coefficient, for ERA-I, ERA-I-R, GPCC and GPCP with respect to SAFRAN data precipitation. Years 2001, 2003 are considered, together with the 1991-2008 period (ERA-I, ERA-I-R, GPCP) or the 1991-2007 period (GPCC).

\begin{tabular}{|c|c|c|c|c|c|}
\hline Year & Score & ERA-I & ERA-I-R & GPCC & GPCP \\
\hline \multirow{4}{*}{2001} & $R^{2}$ & 0.955 & 0.991 & 0.995 & 0.972 \\
\hline & Bias (mm month $\left.{ }^{-1}\right)$ & -22.5 & -11.2 & -5.7 & -1.7 \\
\hline & RMSE (mm month ${ }^{-1}$ ) & 24.3 & 11.7 & 6.6 & 6.2 \\
\hline & Mean Precipitation (SAFRAN) & \multicolumn{4}{|c|}{$1032 \mathrm{~mm}$ in 2001} \\
\hline \multirow{4}{*}{2003} & $R^{2}$ & 0.984 & 0.989 & 0.993 & 0.980 \\
\hline & $\operatorname{Bias}\left(\mathrm{mm}\right.$ month $\left.^{-1}\right)$ & -18.1 & -7.7 & -2.7 & 3.1 \\
\hline & RMSE (mm month ${ }^{-1}$ ) & 19.4 & 8.7 & 3.7 & 5.3 \\
\hline & Mean Precipitation (SAFRAN) & \multicolumn{4}{|c|}{$810 \mathrm{~mm}$ in 2003} \\
\hline [1991-2008] & $R^{2}$ & 0.953 & 0.982 & 0.993 & 0.974 \\
\hline or & Bias (mm month $\left.{ }^{-1}\right)$ & -21.4 & -10.4 & -4.0 & 0.5 \\
\hline \multirow[t]{2}{*}{ ] [1991-2007] } & RMSE (mm month ${ }^{-1}$ ) & 23.7 & 11.7 & 5.6 & 5.9 \\
\hline & Mean Precipitation (SAFRAN) & \multicolumn{4}{|c|}{$951 \mathrm{~mm}$ on average for [1991-2008] } \\
\hline
\end{tabular}

SAFRAN. Over the 1991-2008 period, GPCP only slightly overestimates $\left(0.5 \mathrm{~mm} \mathrm{month}^{-1}\right)$ precipitation in comparison to SAFRAN. Note that while the GPCP/GPCC data sets offer invaluable verification material for precipitation, only high temporal and spatial resolution data sets (such as SAFRAN or ERA-I) can be used for land surface modeling applications.

\subsection{ISR data}

A comparison of three ISR products (ERA-I, SAFRAN and Brion) was performed. SAFRAN cannot be considered as a reference data set for ISR, and the Brion ISR reference is used in this section. The three estimates of the daily ISR over the part of France where Brion data are available, for 2001, 

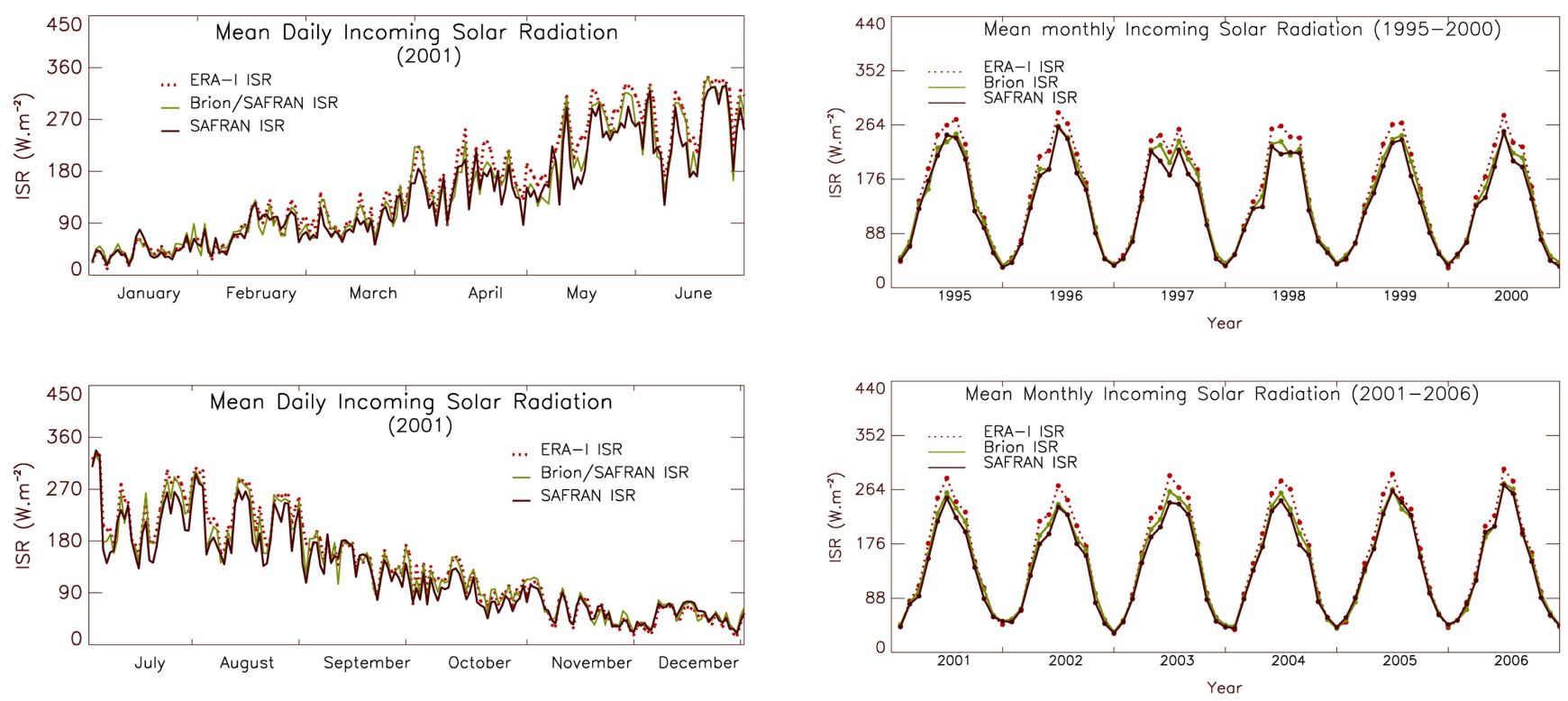

Fig. 7. Mean daily ISR over part of France where there are Brion data (235 grid cells) for SAFRAN, ERA-I and Brion: from (top) January to June 2001, and from (bottom) July to December 2001.

Fig. 8. Mean monthly ISR over part of France where there are Brion data (235 grid cells) for SAFRAN, ERA-I and Brion over the period 1995-2006: from (top) 1995 to 2000 and from (bottom) 2001 to 2006 .

are presented in Fig. 7. Similar results are obtained for 2003 and over the 1995-2006 period (not shown). At the scale of the France domain, the three ISR estimates present similar day-to-day variations. ERA-I correlates very well with SAFRAN and Brion $\left(R^{2}=0.96\right.$ for SAFRAN and $R^{2}=0.98$ for Brion). At wintertime, when the ISR is low, the 3 estimates are almost the same, and the bias is close to zero. At summertime, when the ISR is high, more differences are observed between the three data sets. ERA-I clearly has higher values from February to September. Figure 8 presents the same comparison but for a monthly time step, over the 19952006 period, and illustrates the rather large difference between ERA-I and Brion at summertime. The corresponding scores are listed in Table 4. It can be noted that the difference between ERA-I and SAFRAN is higher than between ERA-I and Brion. ERA-I tends to overestimate the ISR, which is consistent with the underestimation of the precipitation found in Sect. 3.1. Over the 1995-2006 period, the mean overestimation of the monthly ISR by ERA-I represents 7\% of the reference Brion estimates. Although SAFRAN tends to underestimate the ISR, it correlates well with the other estimates.

The square correlation coefficient between ERA-I and SAFRAN time series (daily time step) with Brion, and the mean bias, were calculated for each ERA-I grid cell for the 1995-2006 period and were plotted in Fig. 9. ERA-I correlates better than SAFRAN with the reference Brion product. In coastal regions close to the Atlantic ocean and to the Mediterranean Sea, where SAFRAN correlates less with Brion $\left(R^{2}<0.98\right.$ in Fig. 9) higher correlations of ERA-I with Brion are observed. The same trend is observed in the centre

of France. In general, ERA-I correlates very well with Brion $\left(R^{2}>0.99\right.$ for a large part of France). Correlations between ERA-I and SAFRAN are lower in mountainous areas and in Corsica, but still good: $R^{2}$ values are higher than 0.90 in the Alps and higher than 0.96 in the other mountainous areas and in Corsica. Consistent with Fig. 8, SAFRAN and ERA-I tend to underestimate and overestimate the ISR, respectively, with respect to the Brion ISR. However, fewer ERA-I estimates are affected by a large bias: $8 \%$ and $1.4 \%$ of the grid cells present a mean bias lower than $-20 \mathrm{Wm}^{-2}$ or greater than $20 \mathrm{Wm}^{-2}$, for SAFRAN and ERA-I, respectively. The difference between ERA-I and Brion is relatively small except for Brittany, where ISR is more badly overestimated. The comparison between SAFRAN and ERA-I shows that in the Alps, ERA-I tends to underestimate ISR while it overestimates the values in Corsica and in the Pyrenees.

Table 4 shows the ERA-I or SAFRAN scores with respect to the Brion ISR.

\subsection{Air temperature, air humidity and wind speed}

Quintana-Segui et al. (2008) found that the SAFRAN surface air temperature and relative humidity were well reproduced, presenting no bias. Wind speed was also well reproduced, however it was underestimated by SAFRAN with a mean bias of $-0.3 \mathrm{~m} \mathrm{~s}^{-1}$.

Table 5 presents a comparison (annual bias, RMSE and square correlation coefficient) between ERA-I and SAFRAN for three atmospheric variables ( $T_{\mathrm{a}}, q_{\mathrm{a}}$ and wind speed) spatially averaged over France for the 1991-2008 period. In 
Table 4. Average ISR over the France domain where Brion dara are available, in 2001, 2003, and over the $1995-2006$ period: mean bias (ERA-I minus other data sets), RMSE and squared correlation coefficient for ERA-I and SAFRAN with respect to Brion data (based on daily values), and RMSE and squared correlation coefficient for the spatial repartition of the average annual ISR (for 308 grid cells).

\begin{tabular}{|c|c|c|c|c|}
\hline Year & Score & $\begin{array}{r}\text { ERA-I } \\
(76 \% \text { of France) }\end{array}$ & $\begin{array}{l}\text { SAFRAN } \\
\text { of France) }\end{array}$ & Comparison type \\
\hline \multirow{4}{*}{2001} & $R^{2}$ & 0.97 & 0.96 & \multirow{12}{*}{ Temporal (daily values) } \\
\hline & $\operatorname{Bias}\left(\mathrm{Wm}^{-2}\right)$ & 8.2 & -8.5 & \\
\hline & $\operatorname{RMSE}\left(\mathrm{Wm}^{-2}\right)$ & 18.1 & 18.1 & \\
\hline & Mean ISR Brion & $140 \mathrm{Wm}^{-2}$ & & \\
\hline \multirow{4}{*}{2003} & $R^{2}$ & 0.97 & 0.96 & \\
\hline & $\operatorname{Bias}\left(\mathrm{Wm}^{-2}\right)$ & 9.1 & -9.1 & \\
\hline & $\operatorname{RMSE}\left(\mathrm{Wm}^{-2}\right)$ & 18.8 & 20.2 & \\
\hline & Mean ISR Brion & \multicolumn{2}{|l|}{$152 \mathrm{Wm}^{-2}$} & \\
\hline \multirow{4}{*}{ [1995-2006] } & $R^{2}$ & 0.97 & 0.95 & \\
\hline & $\operatorname{Bias}\left(\mathrm{Wm}^{-2}\right)$ & 9.7 & -6.1 & \\
\hline & $\operatorname{RMSE}\left(\mathrm{Wm}^{-2}\right)$ & 19.8 & 19.4 & \\
\hline & Mean ISR Brion & $142 \mathrm{Wm}^{-2}$ & & \\
\hline \multirow{2}{*}{2001} & $R^{2}$ & 0.91 & 0.63 & \multirow{6}{*}{ Spatial (235 grid cells) } \\
\hline & $\operatorname{RMSE}\left(\mathrm{Wm}^{-2}\right)$ & 9.7 & 12.4 & \\
\hline \multirow{2}{*}{2003} & $R^{2}$ & 0.82 & 0.54 & \\
\hline & $\operatorname{RMSE}\left(\mathrm{Wm}^{-2}\right)$ & 10.0 & 12.6 & \\
\hline \multirow{2}{*}{ [1995-2006] } & $R^{2}$ & 0.89 & 0.58 & \\
\hline & $\operatorname{RMSE}\left(\mathrm{Wm}^{-2}\right)$ & 10.6 & 11.1 & \\
\hline
\end{tabular}

order to investigate the difference in $T_{\mathrm{a}}$ and $q_{\mathrm{a}}$ bias, throughout the diurnal cycle, the comparison analysis was made at 00:00, 06:00, 12:00 and 18:00 UTC. The ERA-I $T_{\mathrm{a}}$ and $q_{\mathrm{a}}$ correlate very well with SAFRAN, with $R^{2}>0.97$, and the mean difference between the two data sets over France is relatively small.

At the scale of the whole country, ERA-I tends to overestimate $T_{\mathrm{a}}$ at 00:00, 06:00 and 18:00 UTC while it tends to underestimate this quantity at 12:00 UTC. That implies that ERA-I tends to reduce the diurnal cycle of $T_{\mathrm{a}}$. This tendency is partly due to the ERA-I $T_{\mathrm{a}}$ considered in this study at $10 \mathrm{~m}$ and not at $2 \mathrm{~m}$ like in SAFRAN. At nighttime, the surface radiative cooling induces slightly lower $T_{\mathrm{a}}$ close to the soil than at $10 \mathrm{~m}$ above the soil, and this is consistent with the biases obtained at 00:00, 06:00 and 18:00 UTC. On the contrary, $T_{\mathrm{a}}$ increases more quickly during the day (e.g. at 12:00 UTC) at $2 \mathrm{~m}$ than at $10 \mathrm{~m}$. In order to assess the impact of comparing SAFRAN and ERA-I $T_{\mathrm{a}}$ at different heights, the ERA-I $T_{\mathrm{a}}$ values at $2 \mathrm{~m}$ were investigated for the year 2001. The ERA-I diurnal cycle amplitude at $2 \mathrm{~m}$ is indeed closer to SAFRAN. However, a reduction in the diurnal cycle of $T_{\mathrm{a}}$ remains and this implies that this effect is not totally linked to the difference in height. While, in 2001, the ERA-I $10 \mathrm{~m}$ diurnal amplitude of $T_{\mathrm{a}}$ is reduced by $1.6 \mathrm{~K}$, the ERA-I $2 \mathrm{~m}$ diurnal amplitude is reduced by
0.7 K: ERA-I overestimates $\left(0.5 \mathrm{~K}\right.$ on average) $T_{\mathrm{a}}$ at $00: 00$ and 06:00 UTC and underestimates ( $0.2 \mathrm{~K}$ on average) this quantity at 12:00 UTC. At 18:00 UTC, ERA-I and SAFRAN $T_{\mathrm{a}}$ at $2 \mathrm{~m}$ are similar. The same comparison was performed for grid cells where ERA-I and SAFRAN altitudes are very close (difference $<10 \mathrm{~m}, 44$ points in France). Over these points, the same $0.7 \mathrm{~K}$ reduction in the diurnal amplitude is observed, showing that the remaining diurnal bias is not caused by differences in altitude. At the grid cell level, more specific information regarding the bias between SAFRAN ( $2 \mathrm{~m}$ ) and ERA-I (10 m) over the 1991-2008 period can be extracted from Fig. 10. Regarding $T_{\mathrm{a}}$ at 00:00, 06:00 and 18:00 UTC, ERA-I overestimates the values from 0.5 to $4 \mathrm{~K}$ for a large part of France. At 00:00, this overestimation concerns the whole France, except for the Pyrenees and Alps piedmonts, where ERA-I tends to underestimate the values from -0.5 to $-4 \mathrm{~K}$. At 06:00 and 18:00 UTC, the overestimation concerns particularly Brittany, the Atlantic coast, mountains (Alps and Pyrenees), and southeastern France, including Corsica. The overestimation is greater in mountainous areas for the whole 1991-2008 period. SAFRAN $(8 \mathrm{~km})$ and ERA-I $(\sim 70 \mathrm{~km})$ do not work at the same spatial scale and for this reason, the topography is represented better by SAFRAN than by ERA-I. In these areas, the overestimation of $T_{\mathrm{a}}$ is linked to the smoother ERA-I topography. 
Table 5. Average $T_{\mathrm{a}}, q_{\mathrm{a}}$, wind speed and ISR for the whole France domain: ERA-I vs. SAFRAN (mean bias (ERA-I minus SAFRAN), RMSE and $R^{2}$ ), based on daily values over the 1991-2008 period, for $T_{\mathrm{a}}$ and $q_{\mathrm{a}}$ at 00:00, 06:00, 12:00 and 18:00 UTC, for wind speed at 06:00 and 12:00 UTC, and for ISR at 12:00 UTC, over France.

\begin{tabular}{clcccc}
\hline Variable & Time & $R^{2}$ & Bias & RMSE & $\begin{array}{c}\text { SAFRAN mean } \\
\text { annual value }\end{array}$ \\
\hline \multirow{5}{*}{ Air Temperature } & 00:00 UTC & 0.98 & $1.09 \mathrm{~K}$ & $1.32 \mathrm{~K}$ & $282.14 \mathrm{~K}$ \\
& 06:00 UTC & 0.99 & $0.52 \mathrm{~K}$ & $0.80 \mathrm{~K}$ & $281.61 \mathrm{~K}$ \\
& $12: 00$ UTC & 0.99 & $-0.48 \mathrm{~K}$ & $0.83 \mathrm{~K}$ & $287.49 \mathrm{~K}$ \\
& $18: 00$ UTC & 0.99 & $0.58 \mathrm{~K}$ & $0.82 \mathrm{~K}$ & $285.63 \mathrm{~K}$ \\
\hline \multirow{5}{*}{ Air Humidity } & 00:00 UTC & 0.99 & $6.2 .10^{-5} \mathrm{~kg} \mathrm{~kg}^{-1}$ & $2.9 .10^{-4} \mathrm{~kg} \mathrm{~kg}^{-1}$ & $6.6 .10^{-3} \mathrm{~kg} \mathrm{~kg}^{-1}$ \\
& 06:00 UTC & 0.99 & $1.3 .10^{-7} \mathrm{~kg} \mathrm{~kg}^{-1}$ & $2.7 .10^{-4} \mathrm{~kg} \mathrm{~kg}^{-1}$ & $6.6 .10^{-3} \mathrm{~kg} \mathrm{~kg}^{-1}$ \\
& $12: 00$ UTC & 0.98 & $-4.7 .10^{-4} \mathrm{~kg} \mathrm{~kg}^{-1}$ & $6.3 .10^{-4} \mathrm{~kg} \mathrm{~kg}^{-1}$ & $7.2 .10^{-3} \mathrm{~kg} \mathrm{~kg}^{-1}$ \\
& $18: 00$ UTC & 0.96 & $-4.7 .10^{-4} \mathrm{~kg} \mathrm{~kg}^{-1}$ & $8.5 .10^{-4} \mathrm{~kg} \mathrm{~kg}^{-1}$ & $7.3 .10^{-3} \mathrm{~kg} \mathrm{~kg}^{-1}$ \\
\hline \multirow{2}{*}{ Wind Speed } & 06:00 UTC & 0.94 & $0.95 \mathrm{~m} \mathrm{~s}^{-1}$ & $0.99 \mathrm{~m} \mathrm{~s}^{-1}$ & $2.5 \mathrm{~m} \mathrm{~s}^{-1}$ \\
& $12: 00$ UTC & 0.92 & $0.60 \mathrm{~m} \mathrm{~s}^{-1}$ & $0.81 \mathrm{~m} \mathrm{~s}^{-1}$ & $3.7 \mathrm{~m} \mathrm{~s}^{-1}$ \\
\hline ISR & $12: 00$ UTC & 0.93 & $23.9 \mathrm{Wm}^{-2}$ & $69.2 \mathrm{Wm}^{-2}$ & $442 \mathrm{Wm}^{-2}$ \\
\hline
\end{tabular}

At 12:00 UTC, ERA-I tends to underestimate $T_{\mathrm{a}}$ for a large part of France (except for central regions) and particularly in coastal regions (Atlantic and Mediterranean coasts and Corsica). In some mountainous areas ERA-I overestimate $T_{\mathrm{a}}$ by more than $4 \mathrm{~K}$. The smoother ERA-I topography on mountainous areas triggers higher $T_{\mathrm{a}}$ values throughout the diurnal cycle and has an clear impact on the spatial distribution of the bias at 12:00 UTC.

Air humidity is not independent from air temperature. When $T_{\mathrm{a}}$ increases, $q_{\mathrm{a}}$ tends to be greater. In this study, air humidity differences between SAFRAN and ERA-I correlate with $T_{\mathrm{a}}$ differences $\left(R^{2}=0.65\right)$. Regarding the diurnal cycle, the conclusions obtained for $T_{\mathrm{a}}$ are valid for $q_{\mathrm{a}}$ and a slightly smaller ERA-I diurnal cycle is observed, with a mean reduction of the diurnal amplitude of $5.3 \times 10^{-4} \mathrm{~kg} \mathrm{~kg}^{-1}$ (Table 5). In 2001, the latter figure is $5.1 \times 10^{-4} \mathrm{~kg} \mathrm{~kg}^{-1}$. Consistent with the results obtained for $T_{\mathrm{a}}$, the analysis of the ERA-I $q_{\mathrm{a}}$ at $2 \mathrm{~m}$, in 2001, presents a smaller reduction of the diurnal amplitude, of $2.8 \times 10^{-4} \mathrm{~kg} \mathrm{~kg}^{-1}$. On average, for the 1991-2008 period, ERA-I has virtually no air humidity bias at 00:00 and at 06:00 UTC, but the spatial distribution of the bias is not homogeneous. The overestimation is marked for 29\% of France (especially in Corsica, in southeastern France and in mountainous areas), with a mean bias of $5.7 \times 10^{-4} \mathrm{~kg} \mathrm{~kg}^{-1}$. Over other regions, ERA-I slightly underestimates (mean bias of $-2.3 \times 10^{-4} \mathrm{~kg} \mathrm{~kg}^{-1}$ ) air humidity (Table 5). The same conclusions can be drawn for 12:00 and 18:00 UTC, except for Brittany and in southeastern France (Mediterranean coast and Corsica) where the bias is very small. In mountainous areas, where the ERA-I altitude is smaller than the SAFRAN altitude, the ERA-I air humidity tends to be higher, which is consistent with the impact of altitude on air humidity. In other regions, it can be concluded that the ERA-I air humidity is really close to SAFRAN.

Regarding wind speed, the correlation between ERA-I and SAFRAN is good $\left(R^{2}>0.9\right)$. However, a rather large bias is observed between the two estimates, of about $0.9 \mathrm{~m} \mathrm{~s}^{-1}$ at 06:00 UTC. ERA-I provides higher wind speed values in a large part of France, except for mountainous areas and for southwestern France where it slightly underestimates the values. However, it must be noted that SAFRAN tends to underestimate wind speed by $0.3 \mathrm{~m} \mathrm{~s}^{-1}$, on average (QuintanaSegui et al., 2008).

\subsection{Performance of ERA-I and ERA-I-R over the SMOSREX site}

In order to investigate possible trends in the time series and to compare SAFRAN and ERA-I over a long period of time, the two data sets were studied at the grid-cell corresponding to the SMOSREX site in southern France, for the 19912008 period. Temporal trends from the SAFRAN data set were studied over France by Vidal et al. (2010) for precipitation and for minimum and maximum air temperature $\left(T_{\min }\right.$ and $T_{\max }$ ), within the 1958-2008 period. They show that for most grid-cells, precipitation trends are not significant, but that significant trends (either positive or negative) can be detected, locally. While trends derived from reference in situ observations are between 0.02 and $0.04^{\circ} \mathrm{Cy}^{-1}$ for $T_{\min }$, and around $0.035^{\circ} \mathrm{C}^{-1}$ for $T_{\max }$, the values derived from SAFRAN are more scattered $\left(-0.04\right.$ to $0.06{ }^{\circ} \mathrm{C} \mathrm{y}^{-1}$ for $T_{\min }$ and 0.01 to $0.08^{\circ} \mathrm{Cy}^{-1}$ for $\left.T_{\max }\right)$. Over the shorter period considered in this study, the following results are found with SAFRAN and ERA-I/ERA-I-R for the SMOSREX site: 

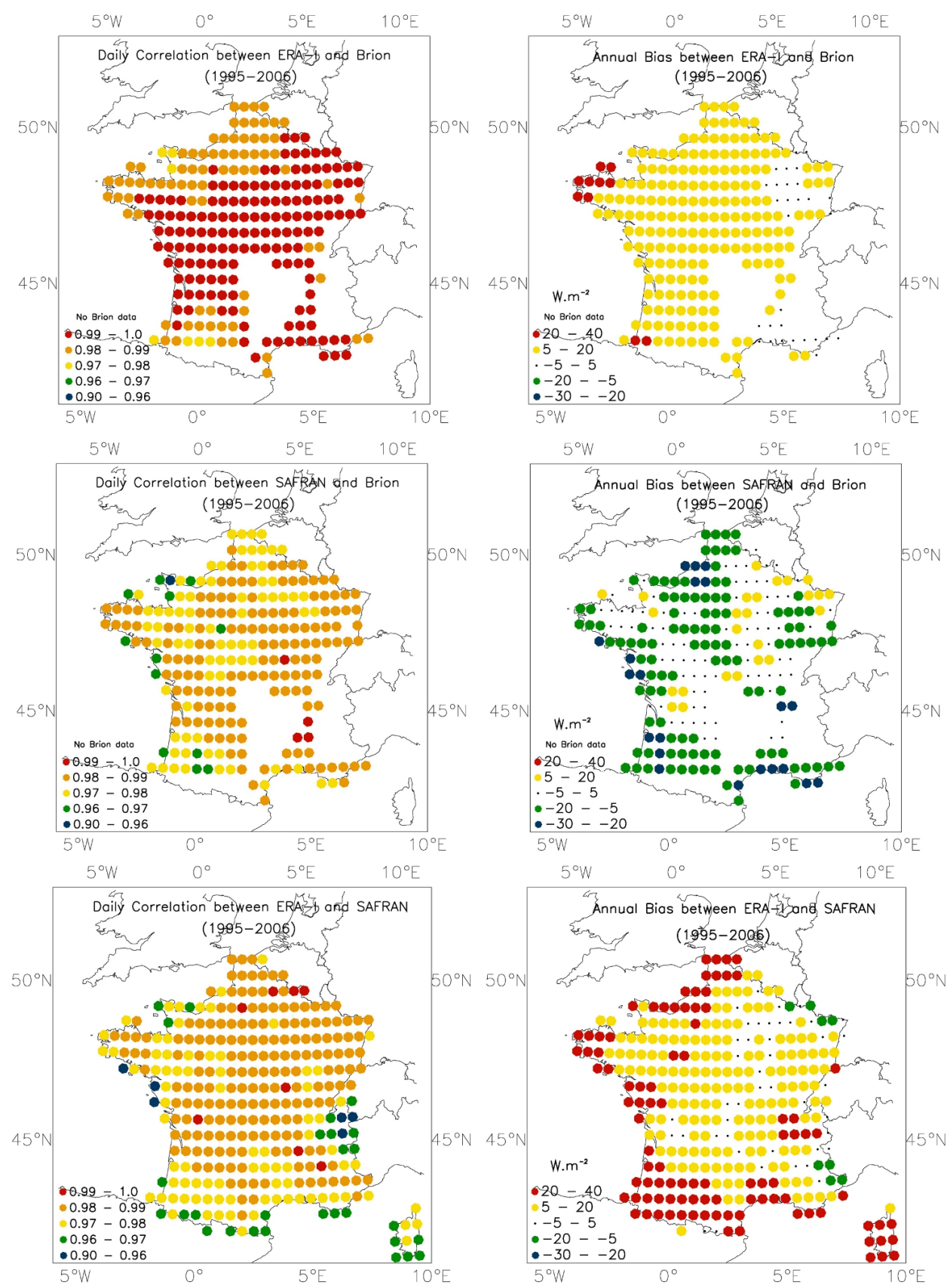

Fig. 9. Daily ISR estimates over the period 1995-2006: (top) ERA-I and (middle) SAFRAN vs. Brion and (bottom) ERA-I vs. SAFRAN in terms of (left) temporal correlation $\left(R^{2}\right)$, and (right) mean bias.

no significant trend is found for precipitation, a significant increase is found for both $T_{\min }$ and $T_{\max }$ for SAFRAN $\left(0.073{ }^{\circ} \mathrm{C} \mathrm{y}^{-1}\right.$ and $0.036^{\circ} \mathrm{Cy}^{-1}$, respectively), and for ERA$\mathrm{I}\left(0.033^{\circ} \mathrm{Cy}^{-1}\right.$ and $0.036^{\circ} \mathrm{Cy}^{-1}$, respectively).

Table 6 presents the comparison scores obtained for each variable. Very good correlations are found between ERA-I and SAFRAN for $q_{\mathrm{a}}$, incoming longwave radiation and ISR $\left(R^{2}>0.7\right)$. Correlations are not as good for $T_{\mathrm{a}}$, wind speed $\left(R^{2} \sim 0.6\right)$, and precipitation $\left(R^{2} \sim 0.5\right)$. The precipitation rescaling of ERA-I data slightly improves the correlation. Regarding the bias, it is relatively high for ISR and precipitation (difference greater than 15\%). The rescaling reduces the magnitude of the bias for the precipitation (for this site, ERA-I-R overestimates the SAFRAN precipitation by $9.5 \%$ ). The mean biases for wind speed and air humidity are close to $-10 \%$ and are smaller for the incoming longwave radiation (about $-4 \%$ ). 


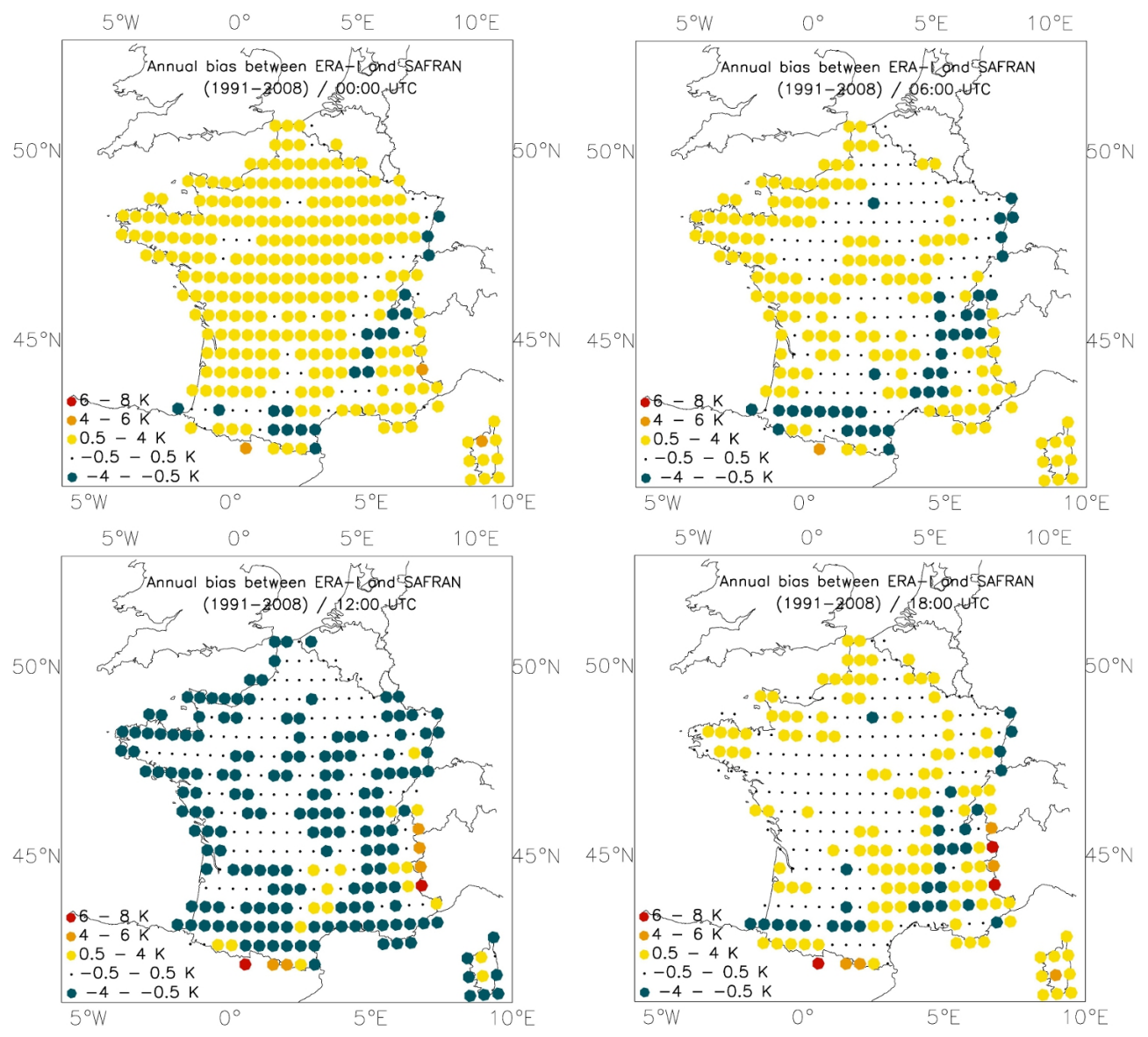

Fig. 10. Daily $T_{\mathrm{a}}$ estimates over the period 1991-2008: ERA-I vs. SAFRAN in terms of mean bias, at (top and left) 00:00, (top and right) 06:00, (bottom and left) 12:00 and (bottom and right) 18:00 UTC.

Table 6. Performance of ERA-I for the SMOSREX site: mean bias (ERA-I minus SAFRAN), RMSE and square correlation coefficient for the different atmospheric variables over the period 1991-2008 (with a daily time step), as compared with SAFRAN.

\begin{tabular}{lrrrrrrr}
\hline Score & $\begin{array}{r}\text { Air } \\
\text { Temperature }\end{array}$ & $\begin{array}{r}\text { Wind } \\
\text { Speed }\end{array}$ & Air Humidity & $\begin{array}{r}\text { Incoming Solar } \\
\text { Radiation }\end{array}$ & $\begin{array}{r}\text { Incoming } \\
\text { Longwave } \\
\text { Radiation }\end{array}$ & $\begin{array}{r}\text { Precipitation } \\
\text { (ERA-I) }\end{array}$ & $\begin{array}{r}\text { Precipitation } \\
\text { (ERA-I-R) }\end{array}$ \\
\hline$R^{2}$ & 0.69 & 0.64 & 0.96 & 0.84 & 0.74 & 0.51 \\
Bias & $-1.2 \mathrm{~K}$ & $-0.3 \mathrm{~m} \mathrm{~s}^{-1}$ & $-8.910^{-4} \mathrm{~kg} \mathrm{~kg}^{-1}$ & $22.7 \mathrm{Wm}^{-2}$ & $-12.9 \mathrm{Wm}^{-2}$ & $-0.015 \mathrm{~mm} \mathrm{~h}^{-1}$ & $0.008 \mathrm{~mm} \mathrm{~h}^{-1}$ \\
RMSE & $4.6 \mathrm{~K}$ & $1.2 \mathrm{~m} \mathrm{~s}^{-1}$ & $1.210^{-3} \mathrm{~kg} \mathrm{~kg}^{-1}$ & $44.9 \mathrm{Wm}^{-2}$ & $23.5 \mathrm{Wm}^{-2}$ & $0.14 \mathrm{~mm} \mathrm{~h}^{-1}$ & $0.15 \mathrm{~mm} \mathrm{~h}^{-1}$ \\
Mean Annual Value & $284.9 \mathrm{~K}$ & $3.1 \mathrm{~m} \mathrm{~s}^{-1}$ & $7.8 .10^{-3} \mathrm{~kg} \mathrm{~kg}^{-1}$ & $146.8 \mathrm{Wm}^{-2}$ & $325.5 \mathrm{Wm}^{-2}$ & $0.084 \mathrm{~mm} \mathrm{~h}^{-1}$ & $0.084 \mathrm{~mm} \mathrm{~h}^{-1}$ \\
Relative Bias (\%) & - & $-9.7 \%$ & $-11.8 \%$ & $15.5 \%$ & $-4.0 \%$ & $-17.9 \%$ & $9.5 \%$ \\
\hline
\end{tabular}

\subsection{Results of offline model simulations}

Although ERA-I correlates well with the French SAFRAN reference, differences are observed between the two data sets. While the precipitation rescaling performed by ECMWF reduced the mean bias by about $50 \%$, no correction was proposed so far for the ISR. Although both ERA-I and SAFRAN correlate very well with Brion (Sect. 3.2), the difference between ERA-I and the reference Brion estimates is larger than the difference between SAFRAN and the reference Brion estimates, especially at summertime. The bias affecting the ERA-I and SAFRAN ISR, may have an impact on soil moisture, LAI and other biophysical variables produced by land surface models forced by these ISR estimates. The precipitation bias of ERA-I and ERA-I-R may also significantly impact the simulations. 

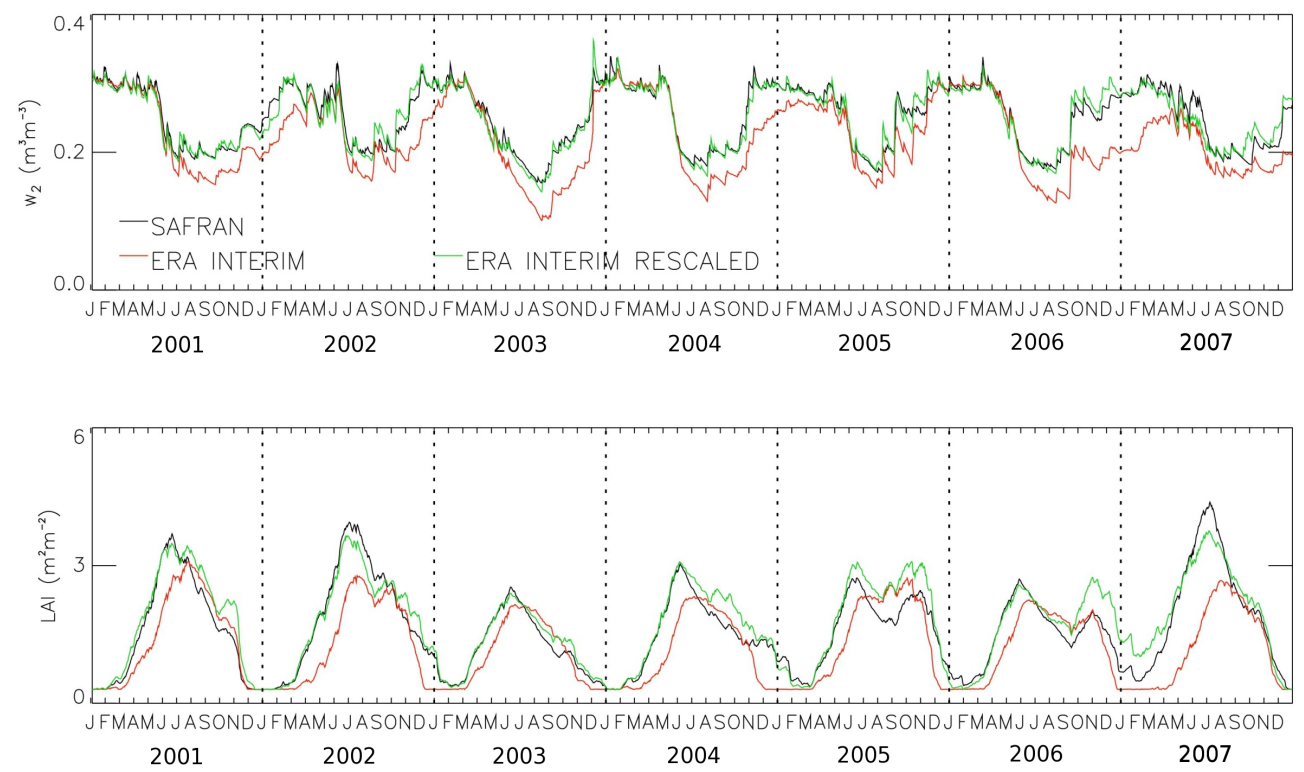

Fig. 11. Impact of the use of different atmospheric forcings (SAFRAN, ERA-I, ERA-I-R) on the ISBA-A-gs simulations of (top) root zone soil moisture and (bottom) leaf area index of the SMOSREX grassland in southwestern France (2001-2007).

An attempt was made to quantify the impact of errors in the atmospheric forcing on the simulations of the ISBA-Ags model for the SMOSREX grassland. Fig. 11 shows the impact of using ERA-I and ERA-I-R on the simulated LAI and $w_{2}$. Regarding $w_{2}$, the ISBA-A-gs simulations forced by ERA-I-R are much closer to the simulations forced by SAFRAN than to the simulations forced by ERA-I. Figure 11 shows a large difference between the ERA-I and ERA-I-R derived simulations of $w_{2}$. Consistent with the underestimation of precipitation by ERA-I (Table 6$), w_{2}$ driven by ERA-I is underestimated in comparison to $w_{2}$ driven by SAFRAN and ERA-I-R, at summertime and also, more often than not, at wintertime. Concerning LAI, similar conclusions can be drawn from Fig. 11. LAI is underestimated when ISBA-A-gs is forced with ERA-I. Moreover, the leaf onset is systematically delayed. This is due to the increased drought limitation to plant growth caused by the underestimated precipitation.

Table 7 presents the various ISBA-A-gs scores obtained for soil moisture, LAI and surface fluxes for the 2001-2007 period (Albergel et al., 2010b), with the different atmospheric forcings (ERA-I and ERA-I-R) compared to the values obtained with the SAFRAN atmospheric data set. The $R^{2}$ value between ERA-I- and SAFRAN-derived simulations of $w_{2}, w_{g}, \mathrm{LAI}$ and $\mathrm{CO}_{2}$ flux are improved by the use of the ERA-I-R precipitation. The use of ERA-I-R, permits to reduce the bias for most variables, particularly for root-zone and surface soil moisture, and for the sensible heat flux $H$. On the other hand, the use of ERA-I-R precipitation tends to increase the bias for the latent heat flux LE. It appears that the precipitation rescaling improves the different $R^{2}$ skill scores for all the variables, especially LAI and the $\mathrm{CO}_{2}$ flux.
This first sensitivity study shows that the bias affecting the ERA-I precipitation has a large impact on the simulation of the different biophysical variables and fluxes, including on their mean value. The sensitivity of ISBA-A-gs to different atmospheric forcings is analyzed further in Sect. 4.

\section{Sensitivity analysis}

\subsection{Impact of ERA-I on simulated biophysical variables}

The biases affecting the ERA-I/ERA-I-R precipitation and the ERA-I ISR, may have a detrimental impact on the simulation of biogeophysical variables (e.g., soil moisture, LAI) and on the simulation of surface fluxes. In Sect. 3.5, it was shown that the use of different precipitation estimates markedly impact the ISBA-A-gs simulations. In order to verify this result and to evaluate the impact of ISR on the ISBAA-gs simulations, a sensitivity study was performed. As described in Sect. 2.5, a reference simulation derived from the whole SAFRAN data set was altered using the ERA-I-R precipitation and the ERA-I ISR. The comparison was performed for the 2001-2007 period and is illustrated by Fig. 12. In order to interpret the different ISBA-A-gs simulations generated using different atmospheric forcings, a cross-analysis of Tables 6 and 7 has to be performed. This analysis is presented below for soil moisture, LAI, and surface fluxes:

- $w_{2}$ : regarding the root zone soil moisture simulations, the three curves of Fig. 12 are very similar. However, the root-zone soil moisture obtained from SAFRAN with ERA-I ISR tends to be lower than the reference SAFRAN simulation. This difference is more 
Table 7. Performance of the ISBA-A-gs model for the SMOSREX site over the 2001-2007 period with different atmospheric forcing data sets (ERA-I, ERA-I-R): mean bias (SAFRAN minus other data sets), RMSE, $R^{2}$ and NASH for various biophysical variables and fluxes obtained from the reference SAFRAN atmospheric forcing data on the SMOSREX site.

\begin{tabular}{|c|c|c|c|c|c|c|c|}
\hline \multirow[b]{2}{*}{$\begin{array}{c}\text { Atmospheric } \\
\text { data set }\end{array}$} & \multirow[t]{2}{*}{ Score } & \multicolumn{3}{|c|}{ Biophysical variables } & \multicolumn{3}{|c|}{ Surface fluxes } \\
\hline & & $\begin{array}{l}w_{2} \\
\text { (Root zone soil } \\
\text { moisture) }\end{array}$ & $\begin{array}{c}\text { LAI } \\
\text { (Leaf Area } \\
\text { Index) }\end{array}$ & $\begin{array}{c}w_{\mathrm{g}} \\
\text { (Surface soil } \\
\text { moisture) }\end{array}$ & $\begin{array}{c}H \\
\text { (Sensible heat } \\
\text { flux) }\end{array}$ & $\begin{array}{c}\text { LE } \\
\text { (Latent heat } \\
\text { flux) }\end{array}$ & $\begin{array}{c}F\left[\mathrm{CO}_{2}\right] \\
\text { (Carbon dioxyde } \\
\text { flux) }\end{array}$ \\
\hline ERA-I & $\begin{array}{l}R^{2} \\
\text { Bias } \\
\text { RMSE } \\
\text { NASH }\end{array}$ & $\begin{array}{c}0.82 \\
0.030 \mathrm{~m}^{3} \mathrm{~m}^{-3} \\
0.039 \mathrm{~m}^{3} \mathrm{~m}^{-3} \\
0.27\end{array}$ & $\begin{array}{c}0.61 \\
0.30 \mathrm{~m}^{2} \mathrm{~m}^{-2} \\
0.67 \mathrm{~m}^{2} \mathrm{~m}^{-2} \\
0.50\end{array}$ & $\begin{array}{c}0.64 \\
0.029 \mathrm{~m}^{3} \mathrm{~m}^{-3} \\
0.054 \mathrm{~m}^{3} \mathrm{~m}^{-3} \\
0.47\end{array}$ & $\begin{array}{c}0.62 \\
-9.7 \mathrm{Wm}^{-2} \\
22.9 \mathrm{Wm}^{-2} \\
-\end{array}$ & $\begin{array}{c}0.71 \\
-0.8 \mathrm{Wm}^{-2} \\
21.0 \mathrm{Wm}^{-2} \\
-\end{array}$ & $\begin{array}{c}0.07 \\
-0.293 \mu \mathrm{mol} \mathrm{m}^{-2} \mathrm{~s}^{-1} \\
1.535 \mu \mathrm{mol} \mathrm{m}^{-2} \mathrm{~s}^{-1} \\
-\end{array}$ \\
\hline ERA-I-R & $\begin{array}{l}R^{2} \\
\text { Bias } \\
\text { RMSE } \\
\text { NASH }\end{array}$ & $\begin{array}{c}0.93 \\
0.001 \mathrm{~m}^{3} \mathrm{~m}^{-3} \\
0.012 \mathrm{~m}^{3} \mathrm{~m}^{-3} \\
0.93\end{array}$ & $\begin{array}{c}0.89 \\
-0.20 \mathrm{~m}^{2} \mathrm{~m}^{-2} \\
0.38 \mathrm{~m}^{2} \mathrm{~m}^{-2} \\
0.84\end{array}$ & $\begin{array}{c}0.66 \\
0.004 \mathrm{~m}^{3} \mathrm{~m}^{-3} \\
0.046 \mathrm{~m}^{3} \mathrm{~m}^{-3} \\
0.61\end{array}$ & $\begin{array}{c}0.62 \\
-6.4 \mathrm{Wm}^{-2} \\
24.8 \mathrm{Wm}^{-2} \\
-\end{array}$ & $\begin{array}{c}0.60 \\
-5.8 \mathrm{Wm}^{-2} \\
26.9 \mathrm{Wm}^{-2} \\
-\end{array}$ & $\begin{array}{c}0.25 \\
0.047 \mu \mathrm{mol} \mathrm{m}^{-2} \mathrm{~s}^{-1} \\
1.311 \mu \mathrm{mol} \mathrm{m}^{-2} \mathrm{~s}^{-1} \\
-\end{array}$ \\
\hline SAFRAN + ERA-I-R precipitation & $\begin{array}{l}R^{2} \\
\text { Bias } \\
\text { RMSE } \\
\text { NASH }\end{array}$ & $\begin{array}{c}0.95 \\
-0.003 \mathrm{~m}^{3} \mathrm{~m}^{-3} \\
0.011 \mathrm{~m}^{3} \mathrm{~m}^{-3} \\
0.94\end{array}$ & $\begin{array}{c}0.86 \\
-0.43 \mathrm{~m}^{2} \mathrm{~m}^{-2} \\
0.58 \mathrm{~m}^{2} \mathrm{~m}^{-2} \\
0.62\end{array}$ & $\begin{array}{c}0.73 \\
-0.008 \mathrm{~m}^{3} \mathrm{~m}^{-3} \\
0.040 \mathrm{~m}^{3} \mathrm{~m}^{-3} \\
0.72\end{array}$ & $\begin{array}{c}0.76 \\
4.8 \mathrm{Wm}^{-2} \\
16.1 \mathrm{Wm}^{-2} \\
-\end{array}$ & $\begin{array}{c}0.74 \\
-4.6 \mathrm{Wm}^{-2} \\
20.5 \mathrm{Wm}^{-2} \\
-\end{array}$ & $\begin{array}{c}0.30 \\
0.065 \mu \mathrm{mol} \mathrm{m}^{-2} \mathrm{~s}^{-1} \\
1.317 \mu \mathrm{mol} \mathrm{m}^{-2} \mathrm{~s}^{-1} \\
-\end{array}$ \\
\hline SAFRAN + ERA-I ISR & $\begin{array}{l}R^{2} \\
\text { Bias } \\
\text { RMSE } \\
\text { NASH }\end{array}$ & $\begin{array}{c}0.97 \\
0.008 \mathrm{~m}^{3} \mathrm{~m}^{-3} \\
0.012 \mathrm{~m}^{3} \mathrm{~m}^{-3} \\
0.93\end{array}$ & $\begin{array}{c}0.94 \\
-0.12 \mathrm{~m}^{2} \mathrm{~m}^{-2} \\
0.26 \mathrm{~m}^{2} \mathrm{~m}^{-2} \\
0.93\end{array}$ & $\begin{array}{c}0.91 \\
0.006 \mathrm{~m}^{3} \mathrm{~m}^{-3} \\
0.024 \mathrm{~m}^{3} \mathrm{~m}^{-3} \\
0.90\end{array}$ & $\begin{array}{c}0.60 \\
-9.2 \mathrm{Wm}^{-2} \\
25.8 \mathrm{Wm}^{-2} \\
-\end{array}$ & $\begin{array}{c}0.63 \\
-0.9 \mathrm{Wm}^{-2} \\
23.5 \mathrm{Wm}^{-2} \\
-\end{array}$ & $\begin{array}{c}0.59 \\
-0.148 \mu \mathrm{mol} \mathrm{m}^{-2} \mathrm{~s}^{-1} \\
0.926 \mu \mathrm{mol} \mathrm{m}^{-2} \mathrm{~s}^{-1} \\
-\end{array}$ \\
\hline
\end{tabular}

pronounced from August to November. Indeed, the period from April to August is characterized by the overestimation of ISR by ERA-I. This tends to enhance evapotranpiration, resulting in a significantly dryer soil from August to November. At wintertime and springtime, when the ERA-I ISR is very close to SAFRAN, the two simulations are similar. The use of the ERA-I-R precipitation data set, has an opposite effect on $w_{2}$ and $w_{2}$ is overestimated, consistent with the $7 \%$ overestimation of the precipitation by ERA-I-R for this site (Table 6). The impact on $w_{2}$ of using the ERA-I-R precipitation is shown in Table 7 by the scores of the SAFRAN + ERA-I-R simulation. The impact is small. As shown by Table 6, the ERA-I-R precipitation is slightly overestimated and this bias produces a slight overestimation of $w_{2}$ (Table 7). The same comparison between SAFRAN and SAFRAN + ERA-I ISR shows the impact of the ERA-I ISR (overestimated by $22.3 \mathrm{Wm}^{-2}$ on average), with an underestimation of $w_{2}$ of $0.008 \mathrm{~m}^{3} \mathrm{~m}^{-3}$, consistent with the enhanced evapotranspiration $\left(+3.4 \mathrm{Wm}^{-2}\right.$ on average). When all the ERA-I-R variables are used, $R^{2}$ is quite good $(0.93)$ and the bias is very small $\left(0.001 \mathrm{~m}^{3} \mathrm{~m}^{-3}\right)$. The overestimation of the ISR offsets the impact of the overestimation of precipitation. On the other hand, using ERA-I, which markedly underestimates precipitation, significantly degrades the scores. In particular, $w_{2}$ is underestimated. It can be concluded that the underestimation of precipitation by ERA-I has a marked impact on $w_{2}$ and that the use of ERA-I-R precipitation reduces this bias.
- LAI: the use of the ERA-I ISR has little impact on the LAI simulations. The difference obtained with SAFRAN with the ERA-I-R precipitation is more significant, with higher LAI values at summertime and during the autumn. This is caused by the reduced drought impact on LAI caused by the overestimated precipitation. Table 7 shows that the use of different precipitation estimates seems to have more impact on LAI (e.g. in terms of $R^{2}$ or Nash score) than on $w_{2}$. The slight overestimation of the precipitation by ERA-I-R produces a marked LAI overestimation (of $0.43 \mathrm{~m}^{2} \mathrm{~m}^{-2}$ on average). The use of the ERA-I ISR has less impact than the use of the ERA-I-R precipitation. As for $w_{2}$, much better scores are obtained by the whole ERA-I-R than with SAFRAN + ERA-I-R precipitation (e.g. Nash of 0.84 and 0.62 , respectively, and a bias reduced by more than $50 \%$ ). The explanation is less evident than for $w_{2}$ since both the overestimation by ERA-I of the ISR, and the overestimation of ISR and precipitation tend to enhance plant growth. It is likely that the use of the ERA-I $T_{\mathrm{a}}, q_{\mathrm{a}}$, and wind speed also impact the LAI simulations. As for $w_{2}$, the score difference between ERA-I and ERA-I-R in Table 7 shows the positive impact of rescaling the ERA-I precipitation.

- $w_{\mathrm{g}}$ : except for the simulation using SAFRAN + ERA-I ISR, surface soil moisture is quite affected by the use of different atmospheric forcings. Precipitation has a particularly large impact on this variable, and contrary to $w_{2}$ and LAI, the whole ERA-I-R simulation markedly degrades the SAFRAN + ERA-I-R precipitation results. 

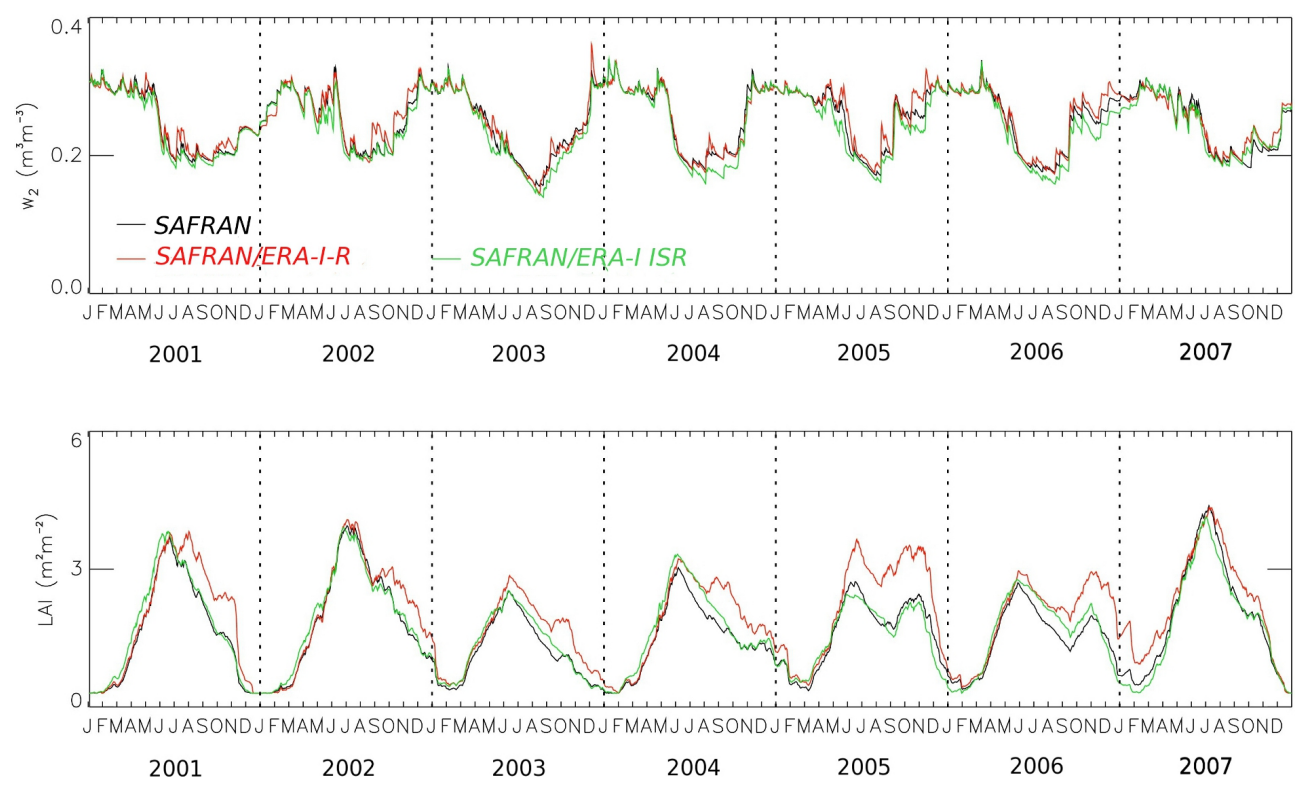

Fig. 12. As in Fig. 11, except for SAFRAN with ERA-I-R precipitation and SAFRAN with ERA-I ISR (2001-2007).

- $H$, LE, $\mathrm{CO}_{2}$ fluxes: regarding the $\mathrm{CO}_{2}$ flux, similarly to LAI and soil moisture, it seems that the quality of precipitation is more essential than the quality of ISR. Regarding $H$ and LE, a different response is observed, with a larger impact of the ERA-I ISR. Overall, Fig. 12 and Table 7 show that the ERA-I ISR and precipitation impact the ISBA-A-gs simulations. The surface fluxes $\left(H, \mathrm{LE}\right.$ and $\left.F\left[\mathrm{CO}_{2}\right]\right)$ are more sensitive to changes in the atmospheric forcing than $w_{2}$ and LAI, and in general, lower $R^{2}$ values are obtained. The score difference between ERA-I and ERA-I-R is particularly marked for $F\left[\mathrm{CO}_{2}\right]$.

Changes in precipitation affect all the simulations generated by ISBA-A-gs, while ISR more particularly affects $H$ and LE.

\subsection{Impact of environmental conditions on ERA-I and ERA-I-R}

Correlations and biases obtained from the comparison between ERA-I (or ERA-I-R for precipitation) and the reference SAFRAN (or Brion for the ISR) data set, were analyzed with respect to various factors, such as altitude, the difference between the altitude used in the SAFRAN analysis and the altitude used in ERA-I, cloud cover, and the mean monthly or annual values of the considered variable.

Regarding the distance to coast, France presents several coast lines (Mediterranean, Atlantic....) with contrasting climatic behaviors, and it was difficult to draw firm conclusions on the impact of this factor. The bias or correlation maps of the atmospheric variables (precipitation, $T_{\mathrm{a}}, q_{\mathrm{a}}$, ISR...) did not show common features close to coastlines. On the other hand, the grid-point altitude derived from SAFRAN may be higher (up to $+1143 \mathrm{~m}$.) or lower (down to $-390 \mathrm{~m}$ ) than the ERA-I altitude. It was found that this factor has significant consequences on $T_{\mathrm{a}}$ and $q_{\mathrm{a}}$. A summary of the main findings of the analysis is given below:

- Precipitation: no correlation was found between the precipitation scores (bias, RMSE or $R^{2}$ ) and the grid points' altitude. Annual and monthly biases of ERAI and ERA-I-R precipitation were compared with the associated mean annual and monthly SAFRAN precipitation estimates (18 annual values, and $12 \times 18$ monthly values). Figure 12 shows that for monthly precipitation values, significant (F-test p-value close to zero) correlations were found with $R^{2}=0.70$ for ERA-I and $R^{2}=0.28$ for ERA-I-R. For annual precipitation values, a significant correlation was found with ERA-I $\left(R^{2}=0.54, \mathrm{p}\right.$-value $\left.<0.001\right)$, but not for ERA-I-R $\left(R^{2}=0.11\right.$, p-value $\left.>0.05\right)$. In brief, the underestimation of precipitation by ERA-I is more marked for larger precipitation amounts (Fig. 13). The remaining bias of the ERA-I-R monthly precipitation depends on the precipitation amount, also, but to a lesser extent. The use of a long time series (1991-2008) permits to map the standard deviations of the scores over the France domain (not shown). For the precipitation data, it is found that the inter-annual $R^{2}$ variability is small (the mean standard deviation of $R^{2}$ over France is 0.13 ) and fairly homogeneous over France. On the other hand, the inter-annual variability of the bias is more diverse and is larger in southern France (Corsica, Pyrenees, the Alps and close to the Mediterranean Sea). A possible explanation, for Mediterranean regions, is 

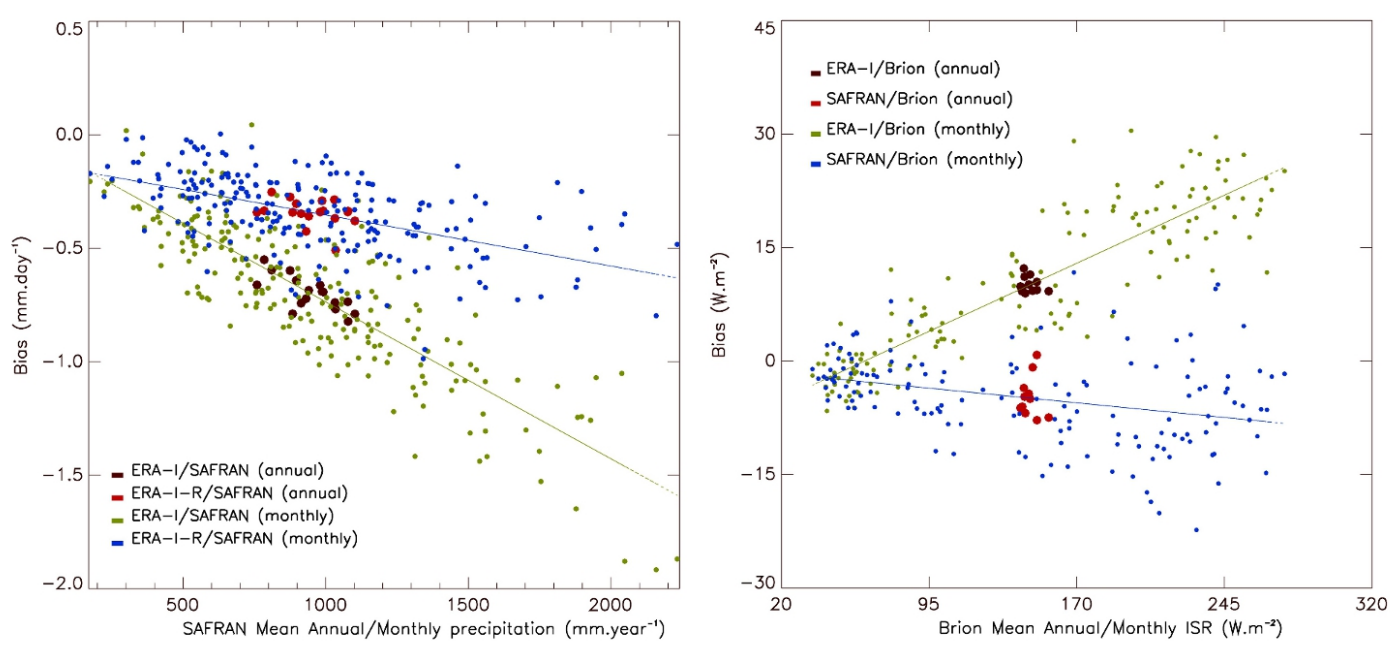

Fig. 13. Biases vs. reference values: (left) precipitation ERA-I and ERA-I-R biases vs. SAFRAN over the 1991-2008 period, (right) ISR ERA-I and SAFRAN biases vs. Brion over the 1995-2006 period. Large and small dots are for annual and monthly values, respectively. Regression lines correspond to monthly values.

that intense precipitation events occur more frequently than in other areas. Figure 6 shows that, like ERAI, ERA-I-R markedly underestimates the most intense precipitation events. Since ERA-I-R tends to overestimate precipitation close to the Mediterranean Sea, more frequent intense precipitation events tend to reduce the mean annual bias. Therefore, the latter varies from one year to another depending on the occurrence of intense precipitation events. As the monthly bias on ERA-I-R precipitation tends to increase with the monthly precipitation value, relative biases (ERA-I-R minus SAFRAN precipitation, scaled by the SAFRAN precipitation) were investigated. The relative biases are similar for low and high precipitation values over France and, more often than not, ERA-I-R underestimates precipitation by about $10 \%$. However, for the Mediterranean regions close to the coast, ERA-I-R locally overestimates precipitation, up to $79 \%$ on a monthly basis. In a few mountainous areas close to Spain and Switzerland, ERA-I-R underestimates precipitation, down to $-49 \%$ on a monthly basis. The most extreme values (either negative or positive) of the relative biases are found in the areas presenting the largest variability of the bias from one year to another (see before).

- ISR: as for precipitation, the scores are not correlated with altitude or with any surface characteristic, but the monthly ERA-I bias correlates well $\left(R^{2}=0.79\right)$ with the mean monthly ISR. In order to investigate the impact of a possible misrepresentation of cloud cover by ERA-I, the ISR biases were compared with the precipitation biases. Although no correlation could be found between the two biases, it is likely that ERA-I tends to underestimate the cloud cover, consistent with the overestimation of the ISR and the underestimation of the precipitation. More studies are needed to investigate the cloud cover impact.

- $T_{\mathrm{a}}$ and $q_{\mathrm{a}}$ : in contrast to precipitation and ISR, the altitude has a marked impact on the biases on $T_{\mathrm{a}}$ and $q_{\mathrm{a}}$. The lapse rates (error per $\mathrm{m}$ height difference) are $7.10^{-3} \mathrm{~K} \mathrm{~m}^{-1}$ and $3.10^{-6} \mathrm{~kg} \mathrm{~kg}^{-1} \mathrm{~m}^{-1}$, for $T_{\mathrm{a}}$ and $q_{\mathrm{a}}$, respectively. The biases were analyzed as a function of the altitude difference between SAFRAN and ERA-I for each ERA-I grid cell, at different times (00:00, 06:00, 12:00 and 18:00 UTC). Significant correlations are obtained, especially at 12:00 and 18:00 UTC $\left(R^{2}=0.74\right.$ and $R^{2}=0.92$ for $T_{\mathrm{a}}$, and $R^{2}=0.54$ and $R^{2}=0.53$ for $q_{\mathrm{a}}$, respectively). On average, for grid-points presenting about the same ERA-I and SAFRAN altitude, no bias is observed for $T_{\mathrm{a}}$, while ERA-I overestimates $q_{\mathrm{a}}$ by $3.10^{-4} \mathrm{~kg} \mathrm{~kg}^{-1}$. When the SAFRAN altitude is greater than the ERA-I altitude (mainly in mountainous areas), ERA-I tends to overestimate both $T_{\mathrm{a}}$ and $q_{\mathrm{a}}$ values.

- Wind speed: for wind speed, no relation could be found between the ERA-I scores and the suspected environmental conditions presented before.

\subsection{Discussion and prospects}

The sensitivity analysis shows that errors in forcing data sets significantly affect the ISBA-A-gs flux and soil moisture simulations. In particular, soil moisture is quite sensitive to errors in precipitation. As soil moisture errors strongly impact the runoff estimates (Decharme and Douville, 2007), improving precipitation estimates is essential for hydrological applications. For this reason, even if the GPCP rescaling improves the ERA-I precipitation estimates, 
more efforts should be made to reduce the remaining biases, either positive or negative. In particular, ERA-I-R tends to overestimate the precipitation in French coastal regions and comparing ERA-I-R with GPCC over the whole Mediterranean basin would be useful. Moreover, a more detailed study of the ERA-I ISR data set could permit the establishment of a link between the biases identified in this study and the cloud cover and, possibly, to propose an ISR rescaling. Satellite-derived ISR values are now available operationally (EUMETSAT LSA-SAF, 2011) and could be used to analyze the ISR error over larger areas.

In order to complete the analysis performed in Sect. 4.1, it would be interesting to consider other sites over France and to compare these new results with those obtained in this study for SMOSREX. These first results did not show a dramatic impact of ISR on the biophysical variables simulated for the SMOSREX site but more studies are needed to investigate the ISR bias effect, together with the precipitation impact. Performing these simulations over the whole France domain, would permit to assess the uncertainties in modeled biophysical variables for various biomes and environmental conditions.

\section{Conclusions}

ERA-I surface meteorological variables and a GPCPcorrected version of ERA-I precipitation (ERA-I-R) were compared with the SAFRAN high resolution atmospheric analysis over France and with the Brion reference Incoming Solar Radiation (ISR) product.

- The daily precipitation estimates produced by ERA-I over France correlate well $\left(R^{2}>0.6\right.$ for $75 \%$ of France, and $R^{2}>0.8$ for $25 \%$ of France) with SAFRAN and are underestimated by $27 \%$. ERA-I-R is less biased (13\%), in comparison with SAFRAN.

- The Incoming Solar Radiation from ERA-I is close to the Brion reference data set. The correlation is very good $\left(R^{2}>0.98\right.$ for $75 \%$ of France). Whereas SAFRAN underestimates the ISR by $5 \%$, ERA-I overestimates the ISR by $6 \%$.

- The precipitation product is less satisfactory in mountainous areas, in Corsica and close to the Mediterranean coast, where the correlations are less significant and the biases are more pronounced.

- ERA-I underestimation and overestimation of precipitation and ISR, respectively, tends to depend on the mean precipitation or ISR associated values.

- Correlations are very high for $T_{\mathrm{a}}, q_{\mathrm{a}}$ and wind speed. Using $10 \mathrm{~m}$ instead of $2 \mathrm{~m} T_{\mathrm{a}}$ (and $q_{\mathrm{a}}$ ), tends to produce slightly lower $T_{\mathrm{a}}\left(q_{\mathrm{a}}\right)$ around midday, and higher $T_{\mathrm{a}}$ at night, at dawn and at dusk. The latter occurs over the whole France domain and particularly in mountainous areas. On the other hand, the underestimation at 12:00 UTC is not systematic: while ERA-I clearly underestimates $T_{\mathrm{a}}$ in coastal regions (where ERA-I overestimates the altitude in comparison to SAFRAN), ERA-I overestimates $T_{\mathrm{a}}$ in mountainous areas (where ERA-I underestimates the altitude).

- The ERA-I altitude underestimation in mountainous areas in comparison to SAFRAN altitude generates an overestimation of $T_{\mathrm{a}}$ and $q_{\mathrm{a}}$ in these regions.

- The impact of using ERA-I and ERA-I-R variables on the biophysical variables simulated by the ISBA-Ags model over a grassland site in southwestern France (SMOSREX) was assessed. It seems that changes in precipitation impact more the simulations than changes in ISR. However, more work is needed in order to analyze the impact of using ERA-I.

Acknowledgements. The work of C. Szczypta was supported by Région Midi-Pyrénées and by Météo-France. This work was performed in the framework of the HYMEX project and S. Lafont was supported by the GEOLAND2 project, cofunded by the European Commission within the GMES initiative in FP7. The work of C. Albergel at CNRM was supported by CNES. The authors thank B. Decharme and J.-F. Mahfouf (CNRM/GAME) for their helpful comments.

Edited by: N. Name

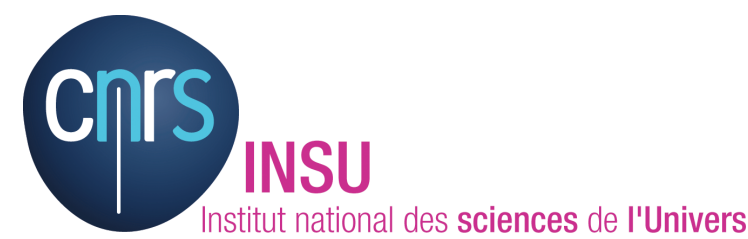

The publication of this article is financed by CNRS-INSU.

\section{References}

Adler, R. F., Huffman, G. J., Chang, A., Ferraro, R., Xie, P.-P., Janowiak, J., Rudolf, B., Schneider, U., Curtis, S., Bolvin, D., Gruber, A., Susskind, J., Arkin, P., and Nelkin, E.: The Version2 Global Precipitation Climatology Project (GPCP) Monthly Precipitation Analysis (1979-Present), J. Hydrometeorol., 4(6), 1147-1167, 2003.

Albergel, C., Calvet, J.-C., Gibelin, A.-L., Lafont, S., Roujean, J.L., Berne, C., Traullé, O., and Fritz, N.: Observed and modelled ecosystem respiration and gross primary production of a grassland in southwestern France, Biogeosciences, 7, 1657-1668, doi:10.5194/bg-7-1657-2010, 2010a.

Albergel, C., Calvet, J.-C., Mahfouf, J.-F., Rüdiger, C., Barbu, A. L., Lafont, S., Roujean, J. L., Walker, J. P., Crapeau, M., and Wigneron, J.-P.: Monitoring of water and carbon 
fluxes using a land data assimilation system: a case study for southwestern France, Hydrol. Earth Syst. Sci., 14, 1109-1124, doi:10.5194/hess-14-1109-2010, 2010b.

Balsamo, G., Boussetta, S., Lopez, P., and Ferranti, L.: Evaluation of ERA-Interim and ERA-Interim-GPCP-rescaled precipitation over the USA, ERA report series, 5, 10 pp., ECMWF, Reading, available at: http://www.ecmwf.int/publications/library/do/ references/list/782009, 2010.

Brion, D., Calvet, J.-C., Le Moigne, P., Ghattas, B., and Habets, F.: Reconstitution par arbres de régression du rayonnement visible descendant horaire sur la France continentale, à partir de données in situ et de simulations: Spatialisation et vérification sur des données indépendantes, CNRMGAME GMME Technical Note, Météo-France, Toulouse, 82, 49 pp., available at: http://hal-meteofrance.archives-ouvertes.fr/ meteo-00514442/fr/, 2005.

Brut, A., Rüdiger, C., Lafont, S., Roujean, J.-L., Calvet, J.-C., Jarlan, L., Gibelin, A.-L., Albergel, C., Le Moigne, P., Soussana, J.-F., Klumpp, K., Guyon, D., Wigneron, J.-P., and Ceschia, E.: Modelling LAI at a regional scale with ISBA-A-gs: comparison with satellite-derived LAI over southwestern France, Biogeosciences, 6, 1389-1404, doi:10.5194/bg-6-1389-2009, 2009.

Calvet, J.-C., Noilhan, J., Roujean, J.-L., Bessemoulin, P., Cabelguenne, M., Olioso, A., and Wigneron, J.-P.: An interactive vegetation SVAT model tested against data from six contrasting sites, Agr. Forest Meteorol., 92, 73-95, 1998.

Decharme, B. and Douville, H.: Global validation of the ISBA subgrid hydrology, Clim. Dyn., 17 pp., doi:10.1007/s00382-0060216-7, 2007.

Dee, D. P., Uppala, S. M., Simmons, A. J., Berrisford, P., Poli, P., Kobayashi, S., Andrae, U., Balmaseda, M. A., Balsamo, G., Bauer, P., Bechtold, P., Beljaars, A. C. M., van de Berg, L., Bidlot, J., Bormann, N., Delsol, C., Dragani, R., Fuentes, M., Geer, A. J., Haimberger, L., Healy, S., Hersbach, H., Hólm, E. V., Isaksen, L., Kållberg, P., Köhler, M., Matricardi, M., McNally, A. P., Monge-Sanz, B. M., Morcrette, J.-J., Peubey, J., de Rosnay, P., Tavolato, C., Thépaut, J.-N., and Vitart, F.: The ERAInterim reanalysis: Conguration and performance of the data assimilation system, ERA report series, 9, 71 pp., ECMWF, Reading, available at: http://www.ecmwf.int/publications/library/do/ references/show?id=89988, 2011.

De Rosnay, P., Calvet, J.-C., Kerr, Y., Wigneron, J.-P., Lemaître, F., Jose Escorihuela, M., Munoz Sabater, J., Saleh, K., Barrie, J., Bouhours, G., Coret, L., Cherel, G., Dedieu, G., Durbe, R., Fritz, N., Froissard, F., Hoedjes, J., Kruszewski, A., Lavenu, F., Suquia, D., Waldteufel, P.: SMOSREX: A long term field campaign experiment for soil moisture and land surface processes remote sensing, Remote Sens. Environ., 102, 377-389, 2006.

Dirmeyer, P. A., Dolman, A. J., and Sato, N.: The pilot phase of the global soil wetness project, B. Am. Meteorol. Soc., 80, 851-878, 1999.

Durand, Y., Brun, E., Merindol, L., Guyomarc'h, G., Lesaffre, B., and Martin, E.: A meteorological estimation of relevant parameters for snow models, Ann. Glaciol., 18, 65-71, 1993.

EUMETSAT: Land surface analysis - Satellite applications facility: Downwelling surface shortwave radiation flux, http://landsaf. meteo.pt, last access: February 2011.

Fuchs, T., Schneider, U., and Rudolf, B.: The Global Precipitation Climatology Centre (GPCC) - in situ observation based precipi- tation climatology on regional and global scale, Geophysical Research Abstracts, EGU General Assembly, 11, EGU2009-10519, 2009.

Georgakakos, K. P. and Carpenter, M.: Potential value of operationally available and spatially distributed ensemble soil water estimates for agriculture, J. Hydrol., 328, 177-191, 2006.

Gibelin, A. L. and Déqué, M.: Anthropogenic climate change over the Mediterranean region simulated by a global variable resolution model, Clim. Dynam., 20, 327-339, 2003.

Huffman, G. J., Adler, R. F., Bolvin, D. T., and Gu, G.: Improving the global precipitation record: GPCP Version 2.1, Geophys. Res. Lett., 36, L17808, doi:10.1029/2009GL040000, 2009.

HyMeX White Book, Draft 1.3.2, 123 pp., available at: http://www. cnrm.meteo.fr/hymex/, last access: August 2010, 2008.

Kerr, Y.: Soil moisture from space: Where are we?, Hydrogeol. J., 15(1), 117-120, 2007.

Le Moigne, P.: SURFEX scientific documentation, Note de centre du Groupe de Météorologie à Moyenne Echelle, Météo-France, CNRM, Toulouse, 87, 211 pp., available at: http://www.cnrm. meteo.fr/surfex/ last access: July 2010, 2009.

Njoku, E. G., Jackson, T. J, Lakshmi, V., Chan, T. K., and Nghiem, S. V.: Soil moisture retrieval from AMSER-E, IEEE Trans. Geosci. Remote Sens., 41(2), 215-123, 2003.

Noilhan, J. and Planton, S.: A simple parameterisation of Land Surface Processes for meteorological model, Mon. Weather Rev., 117, 356-549, 1989.

Noilhan, J. and 5 Mahfouf, J.-F.: The ISBA land surface parameterisation scheme, Global Planet. Change, 13, 145-149, 1996.

Oki, T., Nishimura, T., and Dirmeyer, P.: Validating estimates of land surface parameterizations by annual discharge using total runoff integrating pathways, J. Jpn. Soc. Hydrol. Water Resour., 9, 416-425, 1997.

Oki, T. and Sud, Y. C.: Design of Total Runoff Integrating Pathways (TRIP) - A Global River Channel Network, Earth Interact., 2, 137, 1998.

Pitman, A. J. and Perkins, S. E.: Global and Regional Comparison of Daily 2-m and 1000-hPa Maximum and Minimum Temperatures in Three Global Reanalyses, J. Climate, 22, 4667-4681, doi:10.1175/2009JCLI2799.1, 2009.

Quintana-Segui, P., Lemoigne, P., Durand, Y., Martin, E., Habets, F., Baillon, M., Canellas, C., Franchisteguy, L., and Morel, S.: Analysis of near surface atmospheric variables: Validation of the SAFRAN analysis over France, J. Appl. Meteorol. Clim., 47, 92107, 2008.

Rudolf, B., Beck, C., Grieser, J., and Schneider, U.: Global Precipitation Analysis Products, Global Precipitation Climatology Centre (GPCC), DWD, Internet publication, 1-8, 2005.

Simmons, A., Uppala, S., Dee, D., and Kobayashi, S.: ERA-I : New ECMWF reanalysis products from 1989 onwards, ECMWF Newsletter, 110, 25-35, 2007.

Simmons, A. J., Willett, K. M., Jones, P. D., Thorne, P. W., and Dee, D. P.: Low-frequency variations in surface atmospheric humidity, temperature and precipitation: Inferences from reanalyses and monthly gridded observational data sets, J. Geophys. Res., 115, D01110, doi:10.1029/2009JD012442, 2010.

Vidal, J.-P., Martin, E., Franchistéguy, L., Baillon, M., and Soubeyroux, J.-M.: A 50-year high resolution atmospheric reanalysis over France with the Safran system, Int. J. Climatol., 30, 16271644, doi:10.1002/joc.2003, 2010. 
Wagner, W., Lemoine, G., and Rott, H.: A method for estimating soil moisture from ERS scatterometer and soil data, Remote Sens. Environ., 70, 191-207, 1999a.
Wagner, W., Lemoine, G., Borgeaud, M., and Rott, H.: A study of vegetation cover effects on ERS scatterometer data, Geosci. Remote Sens., 37(2), 938-948, 1999 b. 